\title{
Giorgio Vasari’s The Conception of Our Lady: A Divine Fruit*
}

\author{
Liana De Girolami Cheney \\ Università di Aldo Moro, Bari, Italy
}

\begin{abstract}
The theme of the Conception of the Virgin Mary fascinated 16th-century Mannerist painters, as manifested in Giorgio Vasari's many drawings and paintings and also the numerous replicas in drawings, paintings, and engravings made after his paintings by his contemporary artists. This essay focuses on Vasari's complex iconography of The Conception of Our Lady of 1540 at SS. Apostoli in Florence, Italy. In his documentation of the painting, Vasari never referred to or entitled the painting as an Allegory of the Immaculate Conception or Immaculate Conception but coined it as The Conception of Our Lady (Concezione di Nostra Donna) as it will be referred in this essay. Vasari's complex iconography derived from the writings of the A retine canon Giovanni Pollastra. The Virgin Mary is depicted as a victorious symbol of grace and salvation, triumphing over evil. Rejoicing angels surround her with scrolls containing Latin inscriptions, QUOS EVE CULPA DAAVIT/MARIAE GRATIAE SOLVIT, ECCE AGNIU[S] and UNIUS ONNOSTAA. These joyful words allude to the restoration of the fate of Adam and Eve after eating the forbidden fruit from the Tree of Knowledge in Paradise. A sinuous serpent coils around the fig tree, while tied-up Old Testament and New Testaments wait for forgiveness and salvation. Three considerations are addressed in this essay: (1) discussion of Vasari's recorded commissions; (2) stylistic observations and influences; and (3) interpretation of the imagery, that is, some observations on the symbolism of the painting.
\end{abstract}

Keywords: Giorgio Vasari, symbolism, conception, fig tree, fir tree, grace, Adam and Eve, serpent, Old Testament figures and wisdom

\section{Introduction}

Et egredietur virga de radice lesse et flos de radice eius ascendet ${ }^{1}$

(And there shall come forth a rod out of the stem of Jesse, and a Branch shall grow out of his roots) Isaiah 11:1-2²

\footnotetext{
Liana De Girolami Cheney, Ph.D., Visiting Research in Art History, Political Sciences, Università di Aldo Moro.

Correspondence concerning this article should be addressed to Liana De Girolami Cheney.

*An earlier version of this study was presented at the international conference of the Renaissance Society of America in Berlin in April 2014. The essay benefited by the comments of Profs. Eliana Carrara, Emile Passignant and Ingrid Roland.

${ }^{1}$ See Émile Male, The Gothic Image: Religious Art in France of the Thirteenth Century (English trans. of 3rd ed., London: Collins, 1913, and many other editions), 165-68, for a discussion on Flos, pl flores is Latin for flower. Virga is a "green twig," "rod" or "broom", as well as a convenient near-pun with Virgo or Virgin, which undoubtedly influenced the development of the image. Thus Jesus is the Virga Jesse or "stem of Jesse."

${ }^{2}$ Another translation: "But a shoot shall sprout from the stump of Jesse, and from his roots a bud shall blossom." See Raymond Anderson and Georgene Anderson, The Jesse Tree: The Heritage of Jesus in Stories and Symbols of Advent for the Family (Philadelphia, PA: Fortress Press, 1966). Biblical references for the Tree of Jesse: Is. 6: 14; 11: 1; 53: 2; Num. 24: 17; Matt. 1: 1-16; Luke 3: 23-38; and Rev. 22: 16:

A shoot will spring from the stem of Jesse, and a branch from his roots will bear fruit. The Spirit of the LORD will rest on Him, the spirit of wisdom and understanding, the spirit of counsel and strength, the spirit of knowledge and the fear of the LORD.
} 
The theme of the Conception of the Virgin Mary fascinated 16th-century Mannerist painters, as manifested in Giorgio Vasari's many drawings and paintings and also the numerous replicas in drawings, paintings, and engravings made after his paintings by artists such as Giovanni Battista Naldini, Jacopo Chimenti (Empoli), Carlo Portelli, Niccolò Cicignani (Pomarancio), and Philippe Thomassin. ${ }^{3}$ Vasari's Conception of Our Lady was also highly praised throughout the centuries, for example, in the 16th-century humanists such as Raphael Borghini and Francesco Bocchi, in the 18th century by art writers such as Giuseppe Richa and Luigi Lanzi, and in early 20th century by the renowned historiographer Adolfo Venturi. ${ }^{4}$

Vasari painted three main versions of The Conception of Our Lady executed between 1540 and 1544 are well documented. In 1540, Vasari completed the largest version of The Conception of Our Lady for the banker and art patron Bindo Altoviti, for his private chapel in the church of SS. Apostoli in Florence (see Figures 1a and b, 2 and 3). ${ }^{5}$ In 1544, Vasari painted a smaller version for Altoviti's study (scrittorio) in his villa in Rome (now in the Galleria degli Uffizi in Florence, identified by Paola Barocchi as the Uffizi version). ${ }^{6}$ The third version was finished in 1543 as a triptych for Biagio Mei's private chapel in the church of San Piero at Cigoli (Lucca) (presently in the Pinacoteca Nazionale of Villa Guinigi in Lucca). The triptych consisted of a central panel depicting the Immaculate Conception and two wing panels: Saint Biagio in the left wing, and Saint Eustace in the right wing. ${ }^{7}$

Vasari also painted several copies of the first version, which are found today in museum and churches, e.g.,

\footnotetext{
${ }^{3}$ Before dying, Alessandro Gambalunga of Rimini (1554-1618), lawyer and book collector, requested Thomassin to do an engraving of Giorgio Vasari's Immaculate Conception. L. Tonini, Del riminese, A. G. della Gambalunghiana e de' suoi bibliotecari, in Atti e memorie della R. Deputazione di storia patria per le provincie di Romagna, VIII (1869), 1-38.

${ }^{4}$ See Paola Barocchi, Vasari Pittore (Milan: Club del Libro, 1964), 21. Cinquecento humanists commented as follow: Raffaello Borghini, Il Riposo (Florence 1584), III: 112, in Raffaello Borghini’sIl Riposo, trans. and ed. Lloyd H. Ellis, Jr. (Toronto: University of Toronto Press, 2007), 134-35: "Fu la prima tavola che egli facesse in Firenze e per avventura la migliore e fatta con più diligenza" ("This was the first work [Vasari] made in Florence and perhaps the best panel and done with great diligence"). Francesco Bocchi, Le Belezze della cittàdi Firenze (Florence, 1591), 60-61:

Adamo et Eva da basso con le mani legate, volgendo la testa verso la Vergine, mostrano un certo sospirare affettuoso, bellissimo e raro. Sono tenute queste due figure di somma bellezza, et alcune altre del Testamento Vecchio rendono di vero questa tavola per avventura più di tutte le altre bella che abbia dipinte Giorgio, et anchor più pregiata.

In the eighteenth century, the painting was praised by Giuseppe Rica, Notizie istoriche delle chiese fiorentine, divise ne' suoi quartieri, 4 vols. (Florence: P. G. Viviani, 1754-62), 4:60; Luigi Lanzi, Storia pittorica della Italia dell'ab., 2 vols, (Venice: Remondini, 1795-96), 1:241; and in the early twentieth century by Adolfo Venturi, Storia dell'Arte Italiana, 25 vols. (Milan: Ulrico Hoepli, 1901-39), 24 (1933), 314-15.

${ }^{5}$ See Giorgio Vasari, Le vite de'più eccellenti pittori, scultori e architettori, ed. Rosanna Bettarini and Paola Barocchi, 6 vols (Florence: S.P.E.S., 1987), 7:380-81; Alessandro del Vita, ed., Il Libro delle Ricordanze di Giorgio Vasari (Arezzo: Tipografia Zelli, 1938), 34; Wolfgang Kallab, Vasaristudien (Vienna: W. Grasser and Kiel, 1908), 31; Karl Frey, Der literarische Nachlass Giorgio Vasaris, 2 vols. (Munich: George Müller, 1930), Ricordo 107, 2: 857; and Florian Härb, “Giorgio Vasari Entry,” in Alan Chong, ed., Raphael, Cellini and a Renaissance Banker: The Patronage of Bindo Altoviti (Boston: Isabella Stewart Gardner Museum, 2004), 406-13.

${ }^{6}$ This second painting of 1544 for Bindo Altoviti's study in Rome was recorded in the Guardaroba (Deposits) of the Galleria degli Uffizi since 1771. See no name, Catalogo degli Uffizi (Florence: Uffizi, 1979), P1852; Caterina Caneva, "Giorgio Vasari,” in Il Primato del Disegno (Florence: Centro Di, 1980), 219; and Härb, “Giorgio Vasari Entry,” 412-13. Frey (Der literarische Nachlass Giorgio Vasaris, 1 [1861]) noted the following document in Vasari’s ricordanze:

Ricordo, come a di 9 di Aprile 1544 Messer Bindo Altoviti ebbe da me un quadretto piccolo, pieno di figure, fatte con grandissimadiligentia, per porlo in suo scrittoio; che vera drento ritratto la tavola della concetione della Nostra Donna, come ella sta appunto in Santo Apostolo di Fiorenza, la quale monto scudi quindici di lire sette scudi 15.

(I recall that on April 1544 Messer Bindo Altoviti received from me a small picture, full of figures, made with great diligence, to place in his study; which was a similar copy of the painting of the conception of Our Lady located in San Apostolo [SS Apostoli] in Florence, which brought 15 scudi and 7 lire-scudi 15).

7 See Vasari, Le vite, ed. Bettarini and Barocchi, 7: 383; del Vita, Il Libro delle Ricordanze di Giorgio Vasari, Ricordo 35; and Frey, Der literarische Nachlass Giorgio Vasaris, 1:860-61.
} 
the Museo Statale di Arte Medievale e Moderna in Arezzo, ${ }^{8}$ the Ashmolean Museum of Art in Oxford, ${ }^{9}$ and the Abbey Church of San Salvatore in Fucecchio, near Florence, ${ }^{10}$ other replicas from the Fucecchio version are found in the churches of Santa Maria a Ripa at Empoli, Santa Chiara at San Miniato, and Sant’Agostino a Prato. ${ }^{11}$

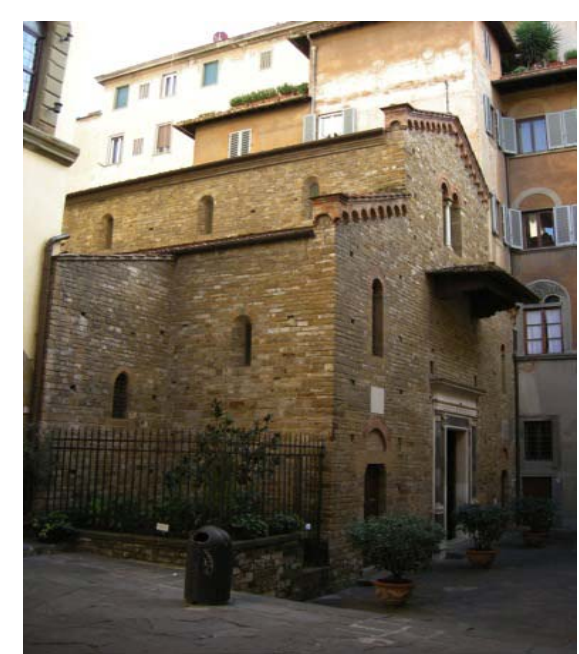

Figure 1a. SS Apostoli, 11th century, renovated 15th and 16th centuries. Exterior. Piazza del Limbo, Florence. Photo credit: author.

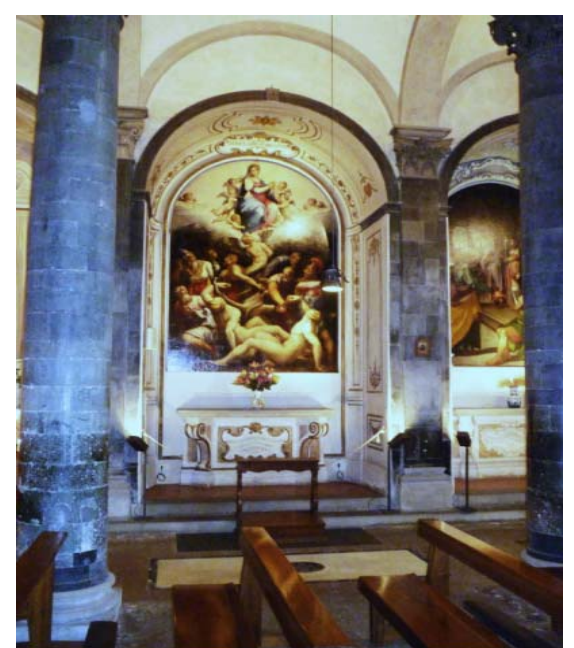

Figure 1b. Bindo Altoviti’s church, location for Giorgio Vasari’s The Conception of Our Lady, 1540. SS Apostoli, Interior. 11th century renovated 15th and 16th centuries. Piazza del Limbo, Florence. Photo credit: author.

\footnotetext{
${ }^{8}$ Attributed to Giulio Mazzoni; see Laura Corti,Giorgio Vasari (Florence: Edam, 1981).

9 See Corti, Vasari, 37; and Kliemann, “Giorgio Vasari” Entry on the Immaculate Conception, in Corti, Vasari, 107. The Oxford version was in the collection Sir Philip Miles, Bt, Leigh Court, Bristol, until 1884, when Christie’s sold it to a private collector. It reappeared in Colnaghi's sales of 1962, when the Ashmolean Museum purchased the painting (Purchased, 1962; WA1962. 26).

${ }^{10}$ See Corti, Vasari, 37; and Kliemann, "Giorgio Vasari” Entry, 104-07. This painting after Vasari was copied by Jacopo Chimenti in 1588 and was restored by Sandra Pucci in 2001. Chimenti made further copies for Santa Maria a Ripa at Empoli, Santa Chiara at San Miniato, and Sant’Agostino in Prato. See Rosanna Caterina Proto Pisani, Empoli, il Valdarno inferiore e la Valdelsa fiorentina (Milan: Mondadori, 1999).

11 See Caneva, “Giorgio Vasari,” 219.
} 


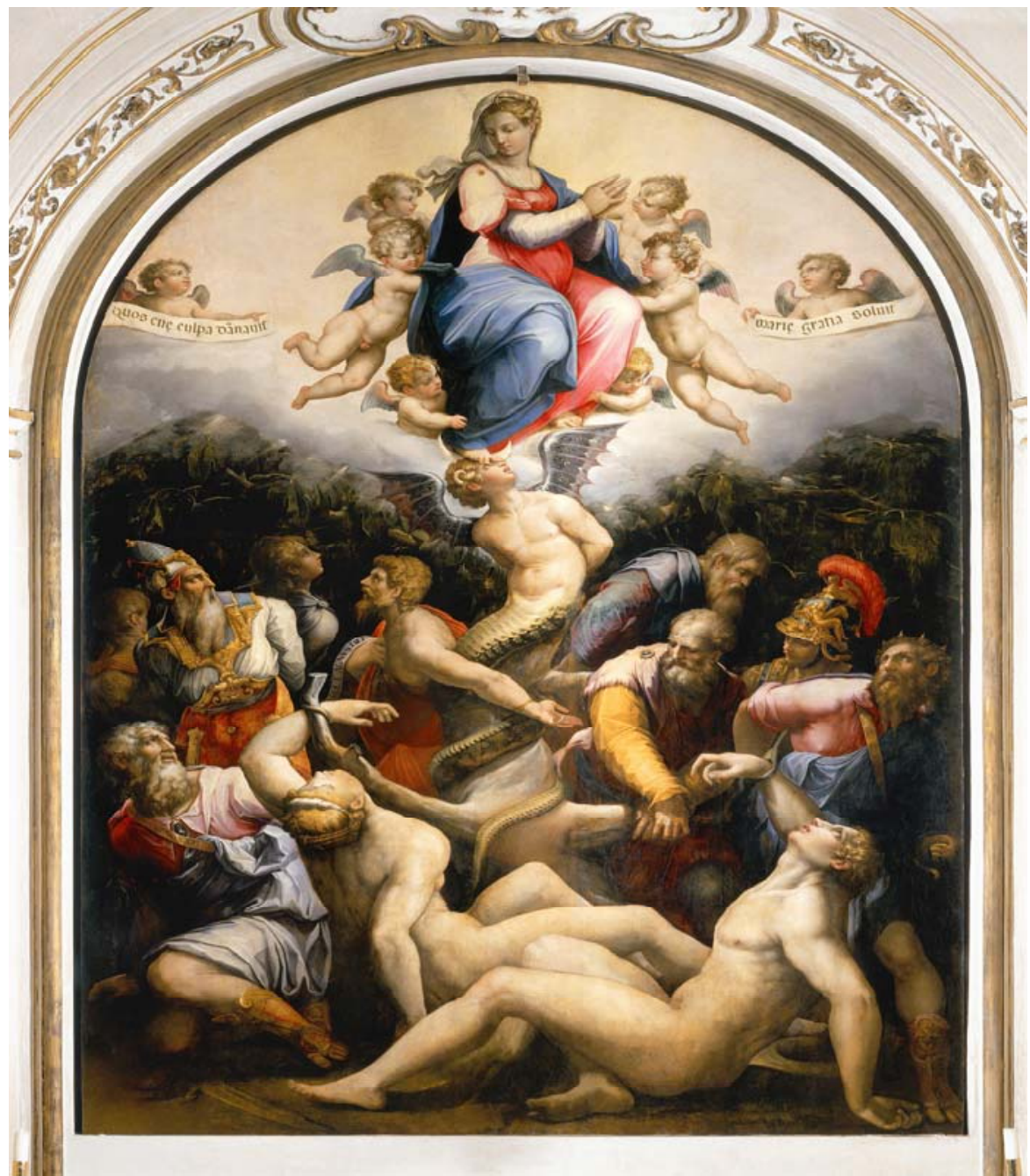

Figure 2. Giorgio Vasari, The Conception of Our Lady, 1540. SS Apostoli, Florence Photo credit: Scala/Art Resource, NY (ART175849).

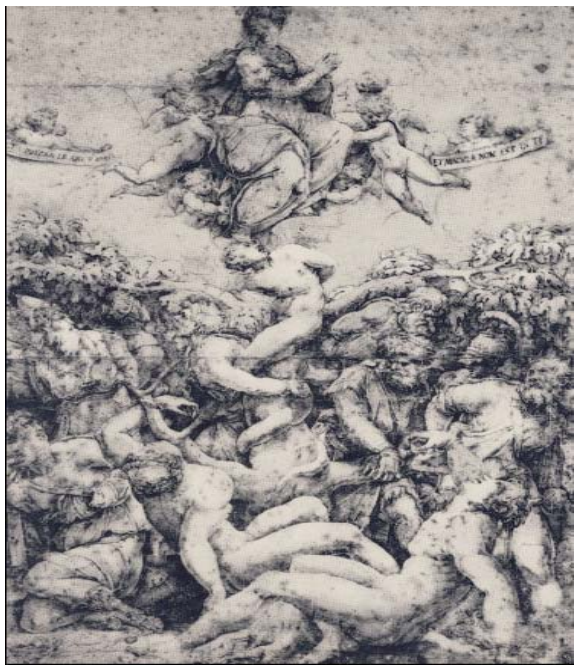

Figure 3. Giorgio Vasari, The Conception of Our Lady, drawing, 1540. Cabinet des Dessins, Louvre, Paris (No. 2082r). Photo credit: RMN-Grand Palais, Musée du Louvre/Stéphane Maréchalle. 
As an exponent of the art of disegno and a proclaimer of disegno being the foundation of artistic creativity, ${ }^{12}$ Vasari completed eight known drawings on the theme of the conception of the Virgin Mary. Some of the attributions are still debated by scholars. They were executed in various drawing media—pencil, pen and ink, and watercolor. Today they are housed in various drawing collections, namely, three at Gabinetto Disegni e Stampe at the Uffizi (Inv. 1181 E, 1183 E, 1179 E), three at the Cabinet des Dessins of the Louvre (Inv. 2082, 2083, and 2197), one in the Devonshire Collection at Chatsworth (Inv. K 297), and another in the Städelsches Kunstinstitut in Frankfurt (Inv. 4454).

Vasari's various drawings and paintings have similarities and differences in colors and composition. For example, the number of angels surrounding the Virgin Mary ranges from four to eight, and there are variances in the placement of the patriarchs and religious figures around the tree trunk, the turning of the serpent's body, and the inclusion of Latin inscriptions.

In this essay, I will not discuss the variances among the many original and replica drawings and paintings or deal with attribution issues regarding these replicas. Some of these are dealt by Florian Härb in his catalogue entry on "Giorgio Vasari's Allegory of the Immaculate Conception."13 In this study, I focus on Vasari's complex iconography of The Conception of Our Lady of 1540 at SS. Apostoli in Florence. This research benefited from the studies of Paola Barocchi, Julian Kliemann, Catherine Goguel, Florian Härb, Dónal O’Connor, Marianna Lora, and Benedetta Moreschini.

This study is composed of three parts: (1) discussion of Vasari's recorded commissions; (2) stylistic observations and influences; and (3) interpretation of the imagery, that is, some observations on the symbolism of the painting.

\section{Recorded Commissions}

There is substantial documentation on these commissions from Vasari's ricordi (artistic records or notations) and vita (autobiography). ${ }^{14}$ In his ricordo of August 10, 1540, Vasari is brief in the description of the Altoviticommission (see Figures 2 and 3). He said:

I remember how on August 10, 1540, Messer Bindo of Antonio Altoviti, citizen of Florence, commissioned a panel painting for his chapel in the church of SS. Apostoli in Florence. The content of the painting was the Tree of Sin, where tied up [to the tree] are Adam and Eve and many patriarchs and prophets. At the top [of the painting] Our Lady dressed with the radiance of the sun and untied them and at her feet the head of the serpent tied up and twisted around the tree. [The painting] is in oil with diligence and for the cost of said of said work ...I was satisfied the payment of 250 scudi. ${ }^{15}$

In his vita, Vasari elaborated on the description of the painting (see Figures 2 and 3):

\footnotetext{
12 See Liana De Girolami Cheney, Giorgio Vasari’s Prefaces: Art and Theory (New York/London: Peter Lang Publishers, 2012), xxxi-lxxiii.

${ }^{13}$ See Härb, “Giorgio Vasari Entry,” 412-13.

14 See Härb, "Giorgio Vasari Entry," 406-13, for the documentation on the paintings as well as on the drawings.

15 See del Vita, Il Libro delle Ricordanze di Giorgio Vasari, 34; Kallab, Vasaristudien, 31; and Frey, Der literarische Nachlass Giorgio Vasaris, Ricordo 107, 2: 857.

Ricordo come a di 10 di agosto 1540 Messer Bindo di Antonio Altoviti cittadino fiorentino mi allogò una tavola da farsi nella Chiesa di Santo Apostolo di Firenze alla Cappella sua drentovi lalbero del Peccato al quale sia legato Adamo et Eva e molti Patriaci et profeti et a sommo la nostra Donna che vestita di Sole con la gratia dello splendor suo gli scioglie et coi piedi calca la testa del serpente legato e avvolto intoro allabero, colorita alio con diligentia e per detto prezzo di essa non si dichiarò senoni che finite secondo che opera fusi dovessi essere dichiarato il pagamento et cosi non simesse ne tempo ne altra cosa. Et cosi mi fu dato la tavola che fu alta braccia 6 et mezzo et larga quarto. Fu stimata detta tavola a di 4 di settembre 1541 da Jacopo du Pontormo pittore da Giovannatonio Sogliani Ridolfo Giriandai scudi 300 et io mi contentai di scudi 250 cioè.
} 
In October 1540, I began to paint a Conception of Our Lady for Messer Bindo’s chapel, that being the dedication. I found this no easy matter, and Messer Bindo and I took the opinion of many mutual friends, men of letters and others and finally I completed it in this manner. In the middle I depicted the tree of original sin, at the foot of which, as the first sinners, I represented Adam and Eve, naked and bound as the first transgressors of the commandment of God, and then one by one, bound to the other branches Abraham, Isaac, Jacob, Moses, Aaron, Joshua, David and the other kings in succession, according to the order of time; all, I say, bound by both arms, excepting Samuel and Saint John the Baptist, who are bound by one arm only, because they were sanctified in the womb. At the tree's trunk, with his tail wound round it, I painted The Ancient Serpent, who having human form from the middle upwards, has the hands bound behind, and upon his head, threading upon his horns, is one foot of the glorious Virgin, who has the other on a Moon. She is clothed with the sun and crowned with twelve stars. The Virgin, I say, is supported in the air within a splendor by many nude little angels, who are illumined by rays issuing from her. The rays pass through the foliage of the tree and shed light upon those bound to it, seeming to loosen their bonds by means of the virtue and grace that they bring from her from whom they proceed. And in the heaven, at the top of the picture are two putti that are holding certain scrolls, in which are written these words: Quos Evae culpa dammavit, Mariae gratia solvit. In short, so far as I can remember I had never before completed any work up to that time with more study or with more lovingness and labor. But all the same, while I perhaps have satisfied others, I did not satisfy myself, I know the time, study and labor that I devoted to it, particularly to the nudes and heads, and, indeed, to every part.

For the labors of that painting Messer Bindo gave me three hundred crowns of gold, besides which, in the following year, he showed me so many courtesies and kindness in his house in Rome, where I made him a copy of the same altarpiece in a little picture, almost in miniature that I shall always feel an obligation to his memory. (see Figure 4) ${ }^{16}$

Three years later, in 1543, Vasari was asked to paint a similar subject for Biagio Mei from Lucca. This composition consisted of a triptych format depicting, in the left and right wings of the altarpiece, Saint Biagio (patron saint of the owner) and Saint Eustace (a stag's hunter), and in the center The Conception of Our Lady. Vasari recorded in his ricordo that he was paid for the commission 161 gold scudi (see Figure 5).

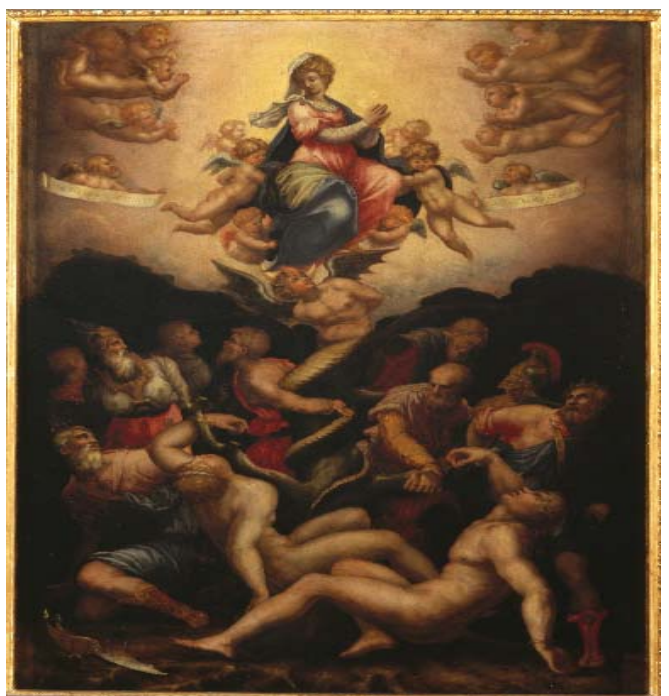

Figure 4. Giorgio Vasari, The Conception of Our Lady, 1540-44. (For Bindo Altoviti’s scrittorio, Roman villa).

Galleria degli Uffizi, Florence Photo credit: Scala/Art Resource, NY (ART185310).

\footnotetext{
${ }^{16}$ See Vasari, Le vite, ed. Bettarini and Barocchi, 7: 380-81; and Giorgio Vasari, Lives of the Most Eminent Painters, Sculptors and Architects, trans. Gaston Du C. De Vere, 3 vols. (New York: N. Abrams, Inc., 1979), 3: 234-35. I consulted this translation and made some corrections to fit Vasari's description. In his Ricordanze, Vasari stated that he received 250 crowns of gold. The Latin phrase says: "Those who blame Eva are absolved by Mary’s grace.”
} 


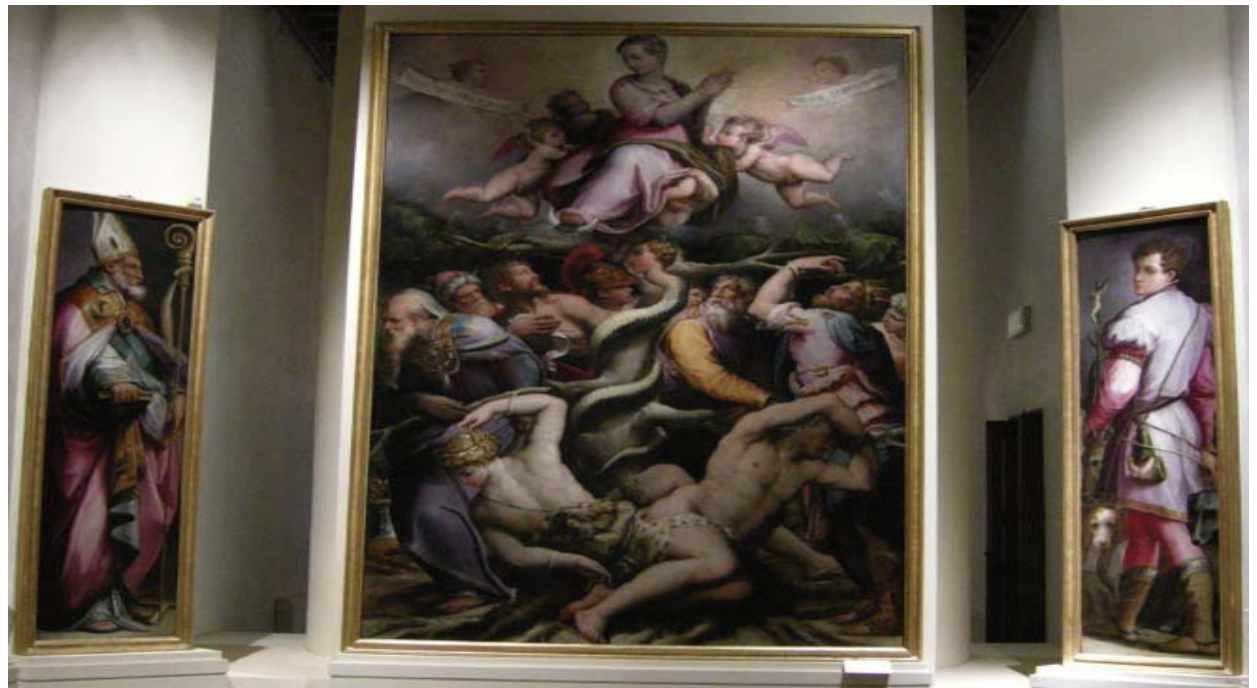

Figure 5. Giorgio Vasari, The Conception of Our Lady, 1543. (For Biagio Mei). Pinacoteca, Lucca. Photo credit: author.

Although the iconographical description for Mei’s triptych is similar to the one of Altoviti's painting, Vasari further elaborated on the action of the Virgin Mary in the Mei's imagery, noting that with the moon below her feet, she crushes the horn of the serpent (“con la luna sotto i piedi gli spezzi le corna”).

I remember how at the end of October of 1543, I left completed in Florence an oil painting of six braccia in height and four braccia in length. [The triptych] contains two wing panels, in one there is the bishop Saint Biagio, and in the other, the hunter, San Eustace. This painting was a commission from Lucca of July 20, 1542, from the Magnificent Messer Biagio Mei, citizen of Lucca. According to a written statement, this painting was to depict in the center the Conception of Our Lady similar to the one executed for Messer Bindo Altoviti in SS. Apostoli in Florence, that is, the tree of sin where tied up are Adam and Eve and other patriarchs with the serpent. Our Lady, surrounded by many putti, dressed with the radiance of the sun, and with the moon below her feet, crushes the horn of the serpent. And [Virgin Mary] with her grace, she releases those who are tied up. I committed to execute it for 150 Italian gold scudi...[but I will do the work for] 161 scudi. $^{17}$

Thus, in his documentation of the painting, Vasari never referred to or entitled the painting as an Allegory of the Immaculate Conception or Immaculate Conception but coined it as The Conception of Our Lady (Concezione di Nostra Donna) as it will be referred in this essay.

\section{Stylistic Influences}

Several Mannerist artists inspired Vasari's stylistic composition, color, and format for the Immaculate Conception. He relied on the drawing of his mentor, Rosso Fiorentino's Study of the Immaculate Conception of 1528 (full drawing in a private collection and details at the École des Beaux-Arts, Paris (Inv. Masson 1198) and

\footnotetext{
17 See del Vita, Il Libro delle Ricordanze di Giorgio Vasari, 43, Carta 43.

Ricordo come a di ultimo di ottobre 1543 io lassai finite in Fiorenza una tavola di braccia 6 alta et quattro larga dipinta aolio con due quadri che dovevano metterli dalle Bande in uno San Biasgio vescovo nellatro Santo Eustachio cacciatore. La quale tavola presi di Lucha perfino sotto il 20 di Luglio 1542 dal Magnifico Messer Biasgio Mei Cittadino luchese la quale tavola come per uno scritto fra di non fatto ero obbligato farvi drento la storia della Concezione di Nostra Donna simile a quella che avevo fatto a Messer Bindo Altoviti in Santo Apostolo di Firenze cioè lalbero del peccato che vi fussi legato adesso adamo et eva et gli altri patriarchi et così il serpente legato che la nostra donna vestita di sole con la luna sotto i piedi gli spezzi le corna et con molti putti attorno et ella con la sua gratia sciolga I legati e cosi volsi obbligarmi al detto farla per prezzo di scudi cento cinquanta doro Italiani da pagarli secondo faro lopera in tutto-scudi 161.
} 
Gabinetto dei Disegni e Stampe at the Uffizi (Inv. 15559F), and on Girolamo Bedoli Mazzola's Study of the Immaculate Conception of 1533-1538 for the Oratory of the Immaculate Conception in Parma (drawing at Cabinet des Dessins at the Louvre, (Inv N.6321r), while the painting is now in the Galleria Nazionale of Parma). ${ }^{18}$ From these artists, Vasari captured the vertical movement of the composition, the circular placement of the religious figures around Adam and Eve, and the contrasting depiction of the clothed holy figure (Virgin Mary) versus the secular nudes (Adam and Eve). Vasari assimilated the interplay of natural forms-vegetation, such as tree and roots-with nude human figures from Jacopo da Pontormo's Study for the lunette with Vertumnus and Pomona of 1519, in the Villa Medici at Poggio a Caiano, at the Galleria degli Uffizi. The circular rotation of tree's branches and roots is surrounded by reclining nudes, who are grabbing and holding on to the branches of the tree. Although critical of Pontormo's project of the Last Judgment for the church of San Lorenzo, Vasari appropriated for his The Conception of Our Lady's composition the elliptical flotation of figures depicted in Pontormo's figures encircling Christ; and for his reclining Adam and Eve, Vasari adapted Pontormo's composition of the reclining figures in the foreground of the Last Judgment. ${ }^{19}$

Other sources of inspiration for Vasari's The Conception of Our Lady, in particular, for the depiction of the female serpent wrapped around a tree, are the passive female serpent observing the actions of Adam and Eve in Raphael's Adam and Eve of 1513 (a fresco ceiling in the Stanza della Segnatura at the Vatican, see Figure 6); and the engaging female serpent with a dramatic long tail coiled around the tree trunk in Michelangelo's Adam and Eve of 1510 (a fresco ceiling on the ceiling in the Sistine Chapel at the Vatican, see Figure 7). From Raphael's imagery, Vasari also assimilated the compositional design of the fig tree and branches in the shape of a canopy and Eve's action of grab bingon to one of the branches while giving Adam the forbidden fruit. In his depiction of the fig tree's composition for The Conception of Our Lady, Vasari also created a canopy for the secular figures, forming a natural realm. From Michelangelo’s imagery, Vasari adapted three compositional actions: (1) Adam's clutching onto one of the fig tree's branches and reaching out for the forbidden fruit; (2) Adam's hypnotized state in observing the serpent's action of tempting Eve with a fig; and (3)

\footnotetext{
${ }^{18}$ See Kliemann, “Giorgio Vasari Entry,” 106-07; and Marianna Lora, “De Rosso à Vasari. Genèse de l’Allégorie de l’Immaculée Conception pour Bindo Altoviti,” Bulletin de l'Association des Historiens de l'art italien 14 (2008), 157-63. Rosso's study was a commission for a painting in the Aretine church of Santa Maria delle Lacrime (today SS. Annunziata). Vasari noted in the vita of Rosso that Lappoli and Rosso collaborated in their imagery: "Bizarrie, che dal bello ingegno di Messer Giovanni Pollastra, canonico Aretine e amico del Rosso, furono trovate” (Vagaries [caprices] composed by the beautiful mind of Messer Giovanni Pollastra, Aretine canon and realized by his friend Rosso). See Vasari, Le vite, ed. Bettarini and Barocchi, 5: 164.

19 See Vasari's vita on Pontormo:

But I have never been able to understand the significance of this scene, although I know that Jacopo had wit enough for himself, and also associated with learned and lettered persons; I mean, what he could have intended to signify in that part where there is Christ on high, raising the dead, and below His feet is God the Father, who is creating Adam and Eve. Besides this, in one of the corners, where are the four Evangelists, nude, with books in their hands, it does not seem to me that in a single place did he give a thought to any order of composition, or measurement, or time, or variety in the heads, or diversity in the flesh-colors, or, in a word, to any rule, proportion or law of perspective, for the whole work is full of nude figures with an order, design, invention, composition, coloring, and painting contrived after his own fashion, and with such melancholy and so little satisfaction for him who beholds the work, that I am determined, since I myself do not understand it, although I am a painter, to leave all who may see it to form their own judgment, for the reason that I believe that I would drive myself mad with it, and would bury myself alive, even as it appears to me that Jacopo in the period of eleven years that he spent upon it sought to bury himself and all who might see the painting, among all those extraordinary figures... Wherefore it appears that in this work he paid no attention to anything save certain parts, and of the other more important parts he took no account whatever. In a word, whereas he had thought in the work to surpass all the paintings in the world of art, he failed by a great measure to equal his own (past) works; whence it is evident that he who seeks to strive beyond his strength and, as it were, to force nature, ruins the good qualities with which he may have been liberally endowed by her.

See Elizabeth Pilliod, “An Introduction to Vasari’s Story,” in Pontormo, Bronzino, and Allori: A Genealogy of Florentine Art (New Haven, CT: Yale University Press, 2001), for a discussion on artist’s rivalry and competitive jealousy.
} 
Adam noticing the snake's enormous tail wrapping around the tree trunk, which forms the initial "S", an allusion of her species' name "serpent” in Renaissance Latin, serpentem (Latin nominative serpens), meaning creeping thing.

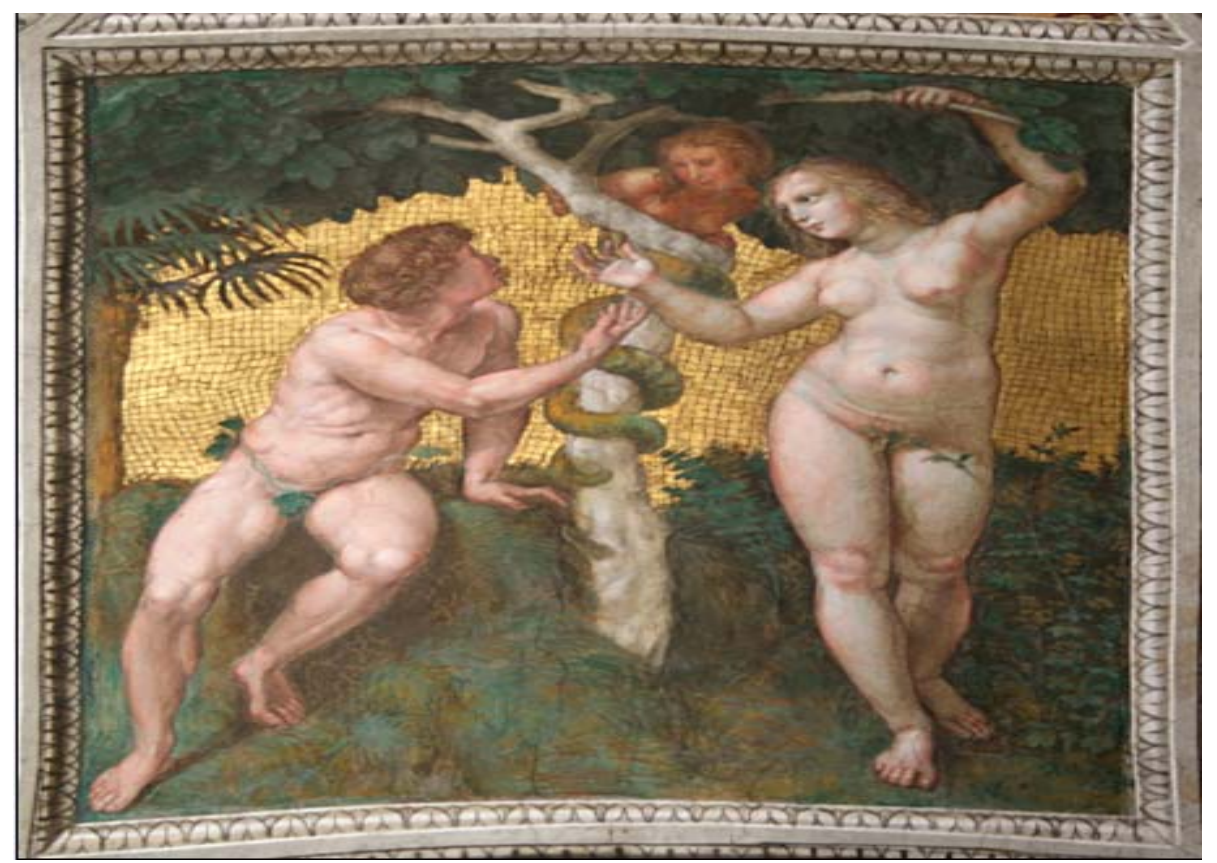

Figure 6. Raphael, Adam and Eve, 1513. Stanza della Segnatura, Vatican Photo credit: Public Domain. Wikipedia.org. Photographer: Jean-Pol GRADMONT.

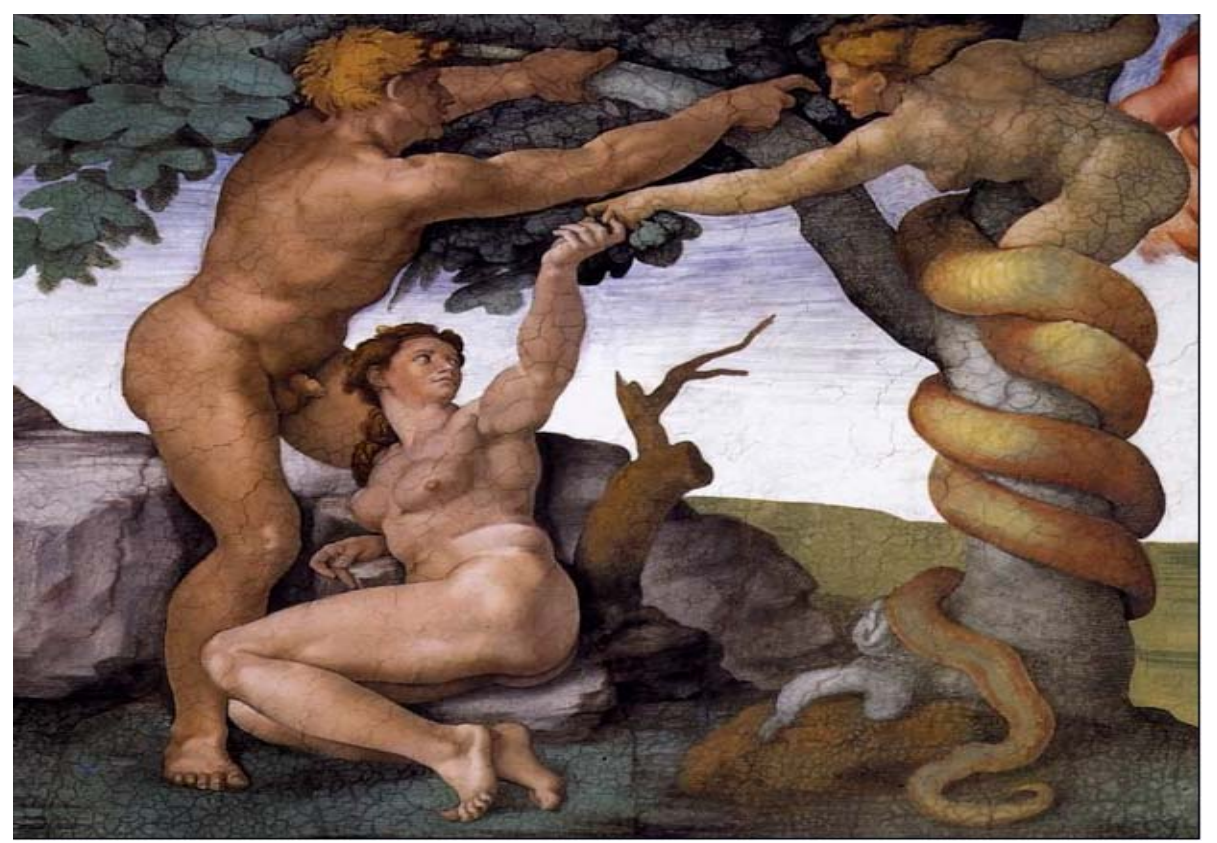

Figure 7. Michelangelo, Adam and Eve, 1510. Sistine Ceiling, Sistine Chapel, Vatican Photo credit: Public Domain. Wikipedia.org.

Vasari's composition of a hopeful Eve, in the nude, tied up and at the foot of a fig tree, turning her eyes toward the heaven for absolution, recalls the design of the Mannerist Sienese painter Domenico Beccafumi's 
Eve of 1515, in the pavement of the main altar in the Duomo of Siena. In the vita of Beccafumi, Vasari highly praised the pavement design, saying: "e per l'ivenzione e per lo disegno fondata e copia di figure, che egli a questo modo diede principio al più bello e al più grande e magnifico pavimento che mai fusse stato fatto..." ([the pavement design was so successful] because of the invention, the powerful design, and the abundance of figures, in this manner, he made the beginning of a new style with the grandest, the most beautiful, and the most magnificent pavement that had ever been made). ${ }^{20}$ In 1586, the printmaker Andrea Adreani reproduced Beccafumi’s Evein a woodcut (Bartsch I, Andrew W. Mellon Fund 1975.110.1).

As seen in his many drawings and paintings for The Conception of Our Lady, Vasari, for the compositional design of the Virgin Mary in the clouds with angels, borrowed from his own work, Assumption of the Virgin of 1532, in the church of Sant'Agostino at Monte San Savino. In turn, Vasari's imagery was influenced by the religious paintings of another Florentine mentor, Andrea del Sarto's Assumptions of 1526 and 1530, now at the Palazzo Pitti in Florence. Thus, Vasari’s Maniera style reveals three main new artistic points: (1) a fusion of Cinquecento brilliant coloration with a new variant of vibrant complementary colors; (2) a transformation of the Quattrocento's horizontal movement of the composition into a rotating and elliptical movement, creating a vertical compressed space; and (3) a liberation in the portrayal of classical figure "in repose”, composing an agitated, dramatic and elaborated expression in figure's treatment.

\section{Symbolism}

In Vasari's The Conception of Our Lady, the Virgin Mary, enthroned on celestial clouds, is shown as a victorious symbol of salvation, triumphing over evil and unbinding her faithful antecedents (see Figure 2). A lustful serpent coils around the Tree of Life while Old Testament figures, patriarchs and prophets, are entrapped in a gloomy abysm. Although tied to fig tree branches, they are waiting to be untied and hoping for forgiveness and restoration of God's divine grace through the Virgin Mary. Rejoicing angels surround her with scrolls containing Latin inscriptions that allude to this joyous event, Quos Eve culpa davvit/ Mariae Gratiae Solvit (Eve had committed a fault/Mary grace paid for it; or, Eve's committed fault was paid with the grace of Mary). A bound John the Baptist holds a scroll with Ecce Agnus Dei (This is the Lamb of God), and Abraham's inscription reads Unius Obnox Am (He [I] was one from the start). These biblical quotations allude to three significant events: (1) the ill fate of Adam and Eve when they disobeyed God by eating the forbidden fruit (fig) from the Tree of Knowledge - the Tree of Good and Evil or the Tree of Life-in Paradise; (2) the Virgin Mary's rescuing divine mission; and (3) Christ's ancestorship and His ministry of salvation for humankind.

Vasari's inventive program for The Conception of Our Lady derives from the writings of the Aretine canon Giovanni Lappoli, known as Pollastra, ${ }^{21}$ as Kliemann has suggested. ${ }^{22}$ Pollastra was Vasari’s friend and tutor, who as a fellow Aretine not only encouraged him to study the classics, but also provided networking

\footnotetext{
${ }^{20}$ See Vasari, Le vite, ed. Bettarini and Barocchi, 5: 173, vita of Beccafumi.

${ }^{21}$ In 1514, Aretine humanist and grammarian Pollastra, Pollastrino, or Polio Pollastrino (1465-1540) became the canon of the Pieve di Santa Maria of Arezzo, which was consecrated as a cathedral in 1525. See Louise G. Clubb and Robert Black, Romance and Aretine Humanism in Sienese Comedy (Siena: La Nuova Italia, 1993), 39-140; Louise G. Clubb, Pollastra and the Origins of the Twelfth Night (London: Ashgate, 2010); and Vasari mentioned Pollastra in the vita of Giovanni Antonio Lappoli Pollastra, his nephew, who was an painter; see Vasari, Le vite, ed. Bettarini and Barocchi, 7: 6-7.

22 See Julian Kliemann, "Vasari, Pollastra e l’Allegoria della Concezione," in Giorgio Vasari. Principi, letterati e artisti nelle carte di Giorgio Vasari, cat. exp. Arezzo, 1981, (Florence, EDAM, 1981, La Toscana nel '500), 103-08; and Giovanni Lappoli Pollastra’s poem to saint Catherine, In laude et gratia della diva et seraphica Catharina da Siena (1505).
} 
connections for him with important patrons of the arts such as Bindo Altoviti. ${ }^{23}$

Much has recently been written on this type of religious imagery, as noted in the exhibition of 2005 in Rome and the catalogue edition of Giovanni Morello, Vincenzo Francia, and Roberto Fusco, Una donna vestita di sole. L'Immacolata Concezione nelle opere dei grandi maestri, ${ }^{24}$ as well as the articles of Marianna Lora (“De Rosso à Vasari. Genèse de l'Allégorie de l’Immaculée Conception pour Bindo Altoviti”) and Dónal O'Connor (“Giorgio Vasari's Allegory of the Immaculate Conception”). ${ }^{25}$ I would like to add to their significant contributions some other observations, namely: (1) analyzing the symbolism of the composition in Neoplatonic terms of celestial and terrestrial realms, and (2) focusing on the symbolism of the tree.

The overall composition includes both the natural and metaphysical realms. The metaphorical division of these realms can be seen at two levels: One separation is between heaven (metaphysical realm) and earth (physical realm); and the other is between two circles of life-contemplative life partaking of the metaphysical realm, and active live experienced in the physical realm (see Figures $8 \mathrm{a}$ and b). ${ }^{26}$ These metaphorical associations further relate to the Neoplatonic symbolism of celestial and terrestrial realms as expounded in Marsilio Ficino's Renaissance Platonic philosophy, where the Christian human soul partakes of these realms. At the time of death, the Human-Soul transcends from the terrestrial realm into the celestial realm, becoming the World-Soul guided by Christian faith and love and, thus, reaching heaven (Paradise) to contemplate God and partake of eternal grace. The impact of Ficino's Neoplatonism on Italian Renaissance and Mannerist art has long been established, in particular on Vasari's paintings. ${ }^{27}$

${ }^{23}$ See Vasari, Le vite, ed. Bettarini and Barocchi, 6: 375 :

By means of Messer Giovanni Pollastra - by the will of God, and to whom I acknowledge and have always acknowledged my every blessings - I was invited to Camaldoli, the center of the Camaldolense Congregation, by the fathers of that hermitage, to see what compositions they wished to have done in their church.

(Per mezzo di Messer Giovanni Pollastra], come Dio volle (alquale sempre mi sono raccomandato e dal quale riconosco et ho riconosciuto sempre ogni mio bene, fu chiamato a Camaldoli, capo della Congregazione Camaldolense, dai Padri di quell'eremo a vedere quello che disegna vano di voler fare nella loro chiesa).

Vasari continued (6: 380):

And I had scarcely completed these works when arrived at Camaldoli Messer Bindo Altoviti, who wished to make transportation of large fir-trees to Rome by the way of the Tiber, for the building of Saint Peter, from the Cella [Celle] San Alberigo, a place belonging to those fathers. Who [Altoviti] seeing all the works I had done there; and by my good fortune liking them, before leaving from there, it was decided that I should paint for him a picture for his church of S. Apostolo [SS. Apostoli] in Florence... Having to give a proof of my powers in Florence skill, where I had not yet made such awork, and having many rivals, and also a desire to acquire a name, I determined that I would do my upmost in that work and put into it all the diligence that I might find possible.

(Né a pena ebbi finite quest'opere, che capito a Camaldoli Messer Bindo Altoviti, per fare dalla cella di Santo Alberigo, luogo di que' padri, una condotta a Roma per via del Tevere, di grossi abeti, per la fabbrica di San Piero; il quale veggendo tutte l'opere da me state fatte in quel luogo, e per mia buona sorte piacendogli, prima che di lì partisse, si risolvé che io gli facessi per la sua chiesa di Santo Apostolo di Firenze una tavola...Me ne venni a Fiorenza e feci la detta tavola. E perché aveva a dare saggio di me a Fiorenza, non avendovi più fatto somigliante opera, aveva molti concorrenti e desiderio di acquistare nome, mi disposi a volere in quell'opera far il mio sforzo e mettervi quanta diligenza mi fusse mai possibile).

${ }^{24}$ See Giovanni Morello, Vincenzo Francia, and Roberto Fusco, Una donna vestita di sole. L'Immacolata Concezione nelle opera dei grandi maestri (Rome: Federico Motta, 2005), 33-53 and 79-91.

${ }^{25}$ See Lora, “De Rosso à Vasari”; Eléonore Fournié and Séverine Lepape-Berlier, “L’Immaculée Conception: une croyance avant d'être un dogme, un enjeu social pour la Chrétienté,” http://acrh.revues.org/4244; and Dónal O’Connor, “Giorgio Vasari’s Allegory of the Immaculate Conception and its Theological Tensions,” in Theological Quarterly 65 (2000), 169-77.

${ }_{26}$ See Marsilio Ficino, Teologia Platonica, trans. from Latin 1474 edition, annotated and ed. Enrico Vitale (Milan: Bompiani, 2011), 161-63 and 1189 on nature, 1509 on metaphysical nature, 1669 and 1763 on the spiritual world, and 1027-29 on the natural world; Marsilio Ficino, ed. Angela Voss (Berkeley, CA: North Atlantic Books, 2006), 83-88; and André Chastel, Marsile Ficin et L'Art (Geneva: Droz, 1975), 93-98.

${ }^{27}$ See Chastel, Marsile Ficin et L'Art, 93-8; and Liana De Girolami Cheney, Giorgio Vasari's Teachers: Sacred and Profane Art (London/New York: Peter Lang Publishing, Inc., 2007), 48-61. 


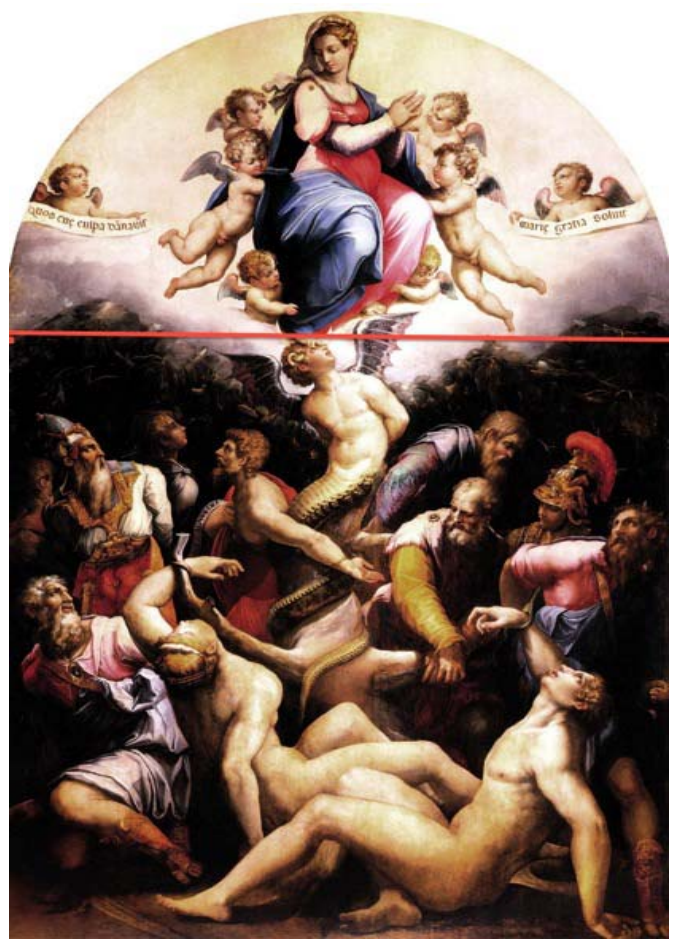

(a)

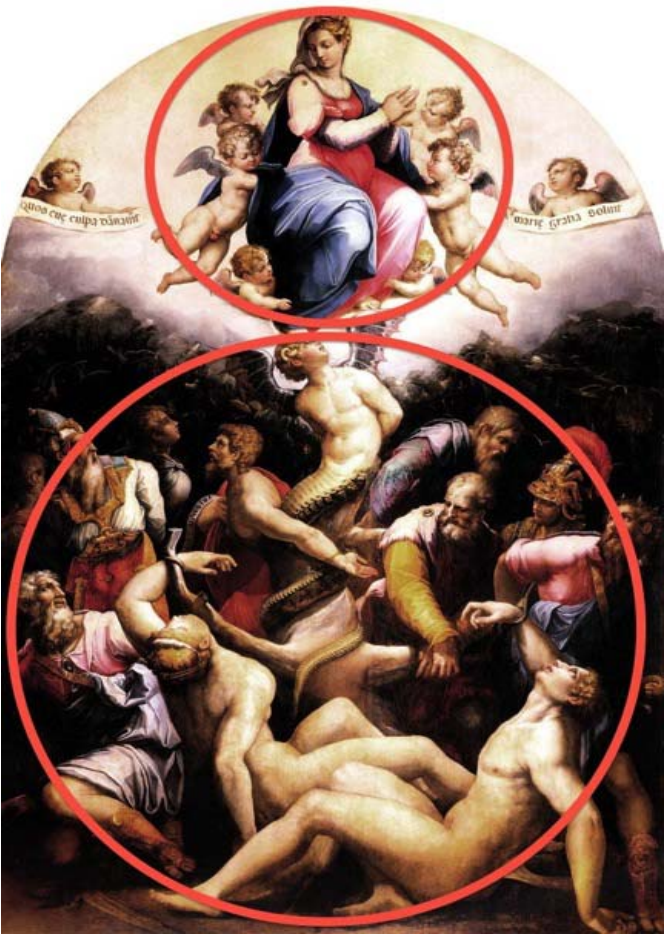

(b)

Figure 8. $a$ and b. Cheney’s Symbolic Designs from Giorgio Vasari, The Conception of Our Lady, 1540. SS Apostoli, Florence. Photo credit: author.

\section{First Separation: Natural Realm}

In the first metaphorical separation in the painting, the natural world is composed by the vegetative fig tree-a symbol of the Tree of Life, The Tree of Knowledge, and Tree of Good and Evil ${ }^{28}$-and human beings. The copious foliage of the fig tree forms a canopy as well as a dark abysm for the human figures. Some of these figures are tied up to the branches of the fig tree trunk. In his vita, Vasari identified these prophetic figures as Abraham, Aaron, Isaac, Jacob (on the left side of the painting), and David, Joshua, and Moses (on the right side of the painting), separately tied to the fig tree's branches, while John the Baptist (on the left side of the painting) and Samuel (on the right side of the painting) are bound together to the same branch. All human figures hope for divine liberation and salvation. Vasari's depiction of these bound Old Testament figures is because of their association with the Tree of Life during their lifetime and, ultimately, their symbolic connection with Christ's cross and His Crucifixion. In the Renaissance, the history and imagery on the symbolism of the cross derived from the writings of Jacobus Voragine's Golden Legend (Legenda aurea), ${ }^{29}$ as seen in the fresco paintings of Piero della Francesca's Legend of the True Cross of 1447-1466, for the Cappella Maggiore of the Church of San Francesco in Arezzo-a fresco cycle wellknown to Vasari. ${ }^{30}$

\footnotetext{
${ }^{28}$ See Adele Nozedar, Signs and Symbols Source Book (New York: Metro Books, 2008), 326, as symbol of fertility and plenty; Michael Zohary, Plants of the Bible (Cambridge: Cambridge University Press, 1982), 58, as a symbol of evil (Matt. 24: 32); and J. C. Cooper, An Illustrated Encyclopaedia of Traditional Symbols (Oxford: Thames and Hudson, 1978), 176-79, association with the Tree of Knowledge as Cosmic Tree.

${ }^{29}$ See Alphonse Napoleon Didron, Christian Iconography, 2 vols. (New York: Frederick Unga, 1851, repr. 1965), Section on the Legend of the Cross 1: 367-417.

${ }^{30}$ See Liana De Girolami Cheney, “Giorgio Vasari’s Saint Francis: An Aretine Fervor,” Journal of Literature and Art Studies, Vol. 5, No. 10 (October 2015), 859-73.
} 
In Vasari's The Conception of Our Lady, a bearded Abraham, the Father of Humankind, rests his legs on a pile of wood and has incised in his chest strap a Latin inscription, Unius Obnox Am (He [I] was one from the start) (see Figure 9). This inscription identifies Abraham not only as the founder of the Davidic line, but also as the first one to use the tree (wood) for the sacrifice of his son Isaac, following God's request (Gen. 22: 1-14). ${ }^{31}$ A large golden brooch holding his vest contains a cameo illustrating the attempted sacrifice of Isaac. At Abraham's feet, Vasari painted two attributes, a sword and an ointment jar or oil lamp. The sword reinforces the sacrificial theme seen in the cameo. The ointment jar is associated with three figures in the painting: Adam, Aaron, and John the Baptist. Before his death, Adam asked the Angel of Paradise for a few drops of oil of mercy to heal his sickness. The Angel instead provided him with another precious gift, a branch from the Tree of Life (Gen. 2: 7-9, 18-24). ${ }^{32}$ In the Old Testament, according to the Hebraic mashach (anoint) tradition, Aaron was anointed with oil as leader of the Israelites, creating a peaceful life for the Israelites (Leviticus Rabbahx, Midras, cxxxiii). ${ }^{33}$ In the New Testament, John the Baptist is associated with a "burning and shining lamp with the fire and light serving as symbols of the divine presence-an epiphany, revelation of the mind and purposes of God” (John 5: 35).

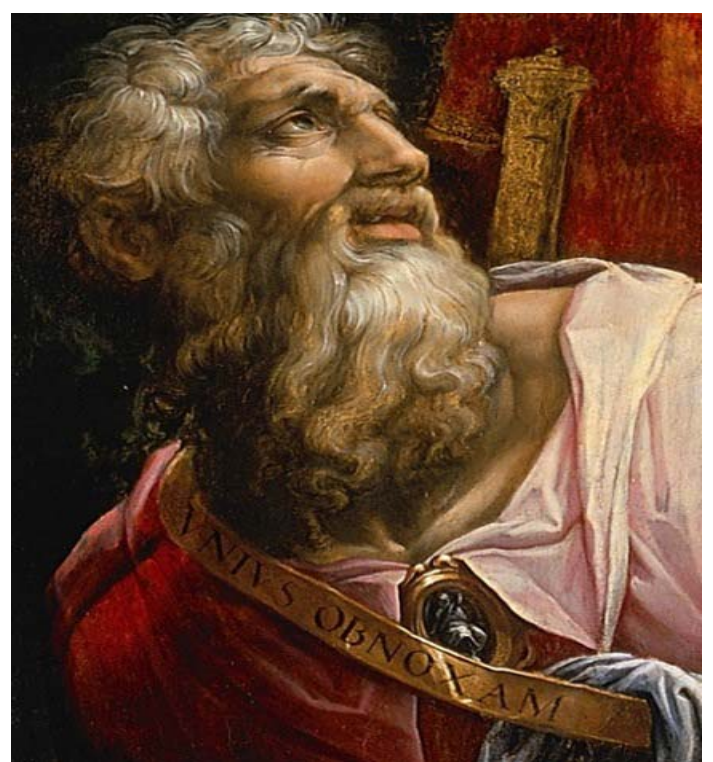

Figure 9. Giorgio Vasari, Abraham, det., The Conception of Our Lady, 1540. SS Apostoli, Florence. Photo credit: Scala/Art Resource, NY (ART175849).

In Vasari's painting, standing behind Abraham, aging and bearded, Aaron is identified as a Jewish High Priest dressed in his finest, wearing a Hebraic ruler's attire, an elaborate miter, a breastplate, a sash, and an apron or ephod. Behind Aaron are the offspring of Abraham-Isaac and Jacob, the founders of Israel. Jacob is depicted wearing a goatskin cap, alluding to his anointed kingship (Gen 25: 27-34). ${ }^{34}$ The figure of Isaac is difficult to identify, since his head is turned away from the viewer, and no attributes are visible. However, the

\footnotetext{
31 See Didron, Christian Iconography, 1: 370.

32 See Didron, Christian Iconography, 1: 368.

33 In the other versions, Vasari's ointment jar or oil lamp, alluding to his power to anoint the next ruler of the Israelites, is clearly visible.

${ }^{34}$ See Liana De Girolami Cheney, “Giorgio Vasari’s The Dream of Jacob,” in Vasari in Context, ed. Liana De Girolami Cheney and Yael Even, ERIC Special Edition (Summer 2013), 7-25.
} 
Bible notes, "He [Isaac] carried his own wood for the sacrifice” (Gen. 22: 1-14). ${ }^{35}$ Since Abraham’s sacrifice of his son, Isaac, to God did not occur, Vasari placed the piles of wood under Abraham limbs. Perhaps Isaac's turned head and long neck with a large scar may allude to Abraham's attempt to sever his head.

In the painting, the Old Testament images on the other side of the Tree of Life (right side of the painting) are composed of a trio above Adam: King David, the soldier Joshua, and the prophet Moses. These three are also connected to the symbolism of the tree and are known for their leadership to free the Israelites, guiding them to the Promised Land. The prophet, judge, and ruler Samuel, behind Moses, is tied up to the same branch as John the Baptist, which reminds the viewer of his role and mission to have anointed David as King of Israel.

Vasari's depicted Old Testament figures refer to their associated with a wooden tree or a fig tree during their lives, hence their binding to the fig tree branches. Not by accident, Vasari included the New Testament figure of John the Baptist, facing Aaron, his grandfather. Elizabeth, John’s mother, was Aaron's daughter (Luke 1: 5). John prophesied the messianic role of Christ, his cousin, as well as paved the way for His coming (The Book of Malachi 3: 1). ${ }^{36}$ Vasari portrayed John partially covered with a sheep-skin, holding a red scarf and a scroll with the Latin inscription, Ecce Agnus Dei (Behold the Lamb of God), which affirms the wonderment of the coming of Christ as well as His suffering (Isaiah 53: 7) and crucifixion (see Figure 10). ${ }^{37}$ John's presence in the painting is a confirmation that the Son of God would be made flesh through the Virgin Mary's conception.

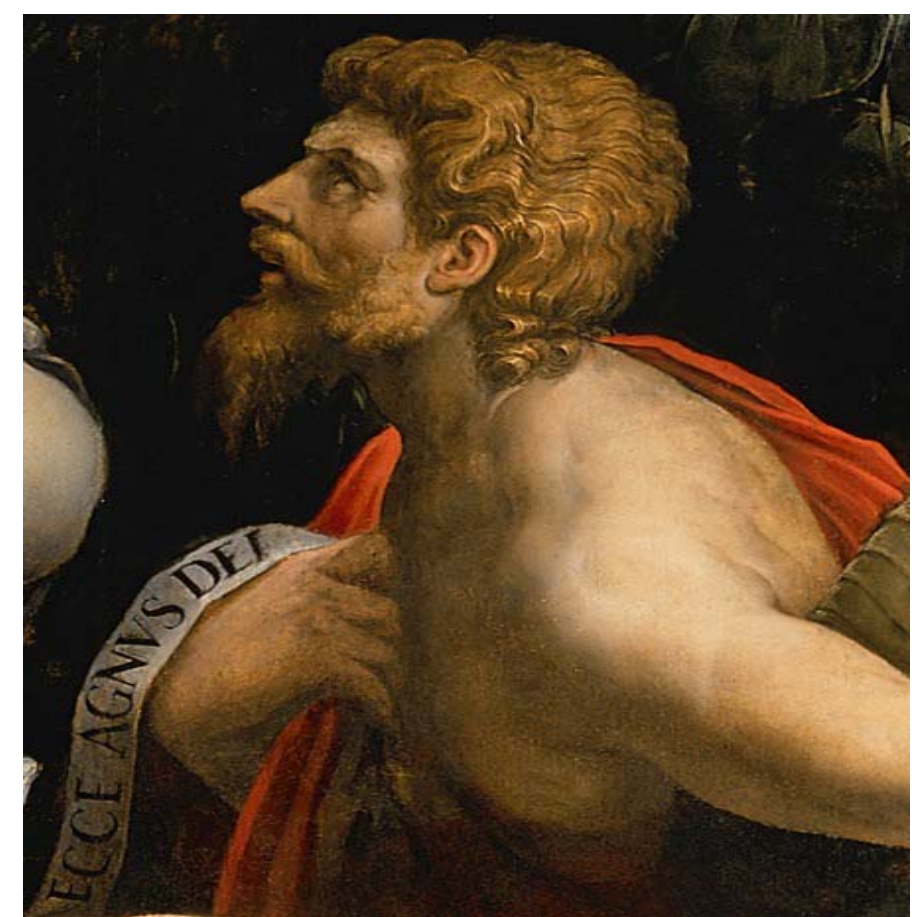

Figure 10. Giorgio Vasari, John the Baptist, det., The Conception of Our Lady, 1540. SS Apostoli, Florence. Photo credit: Scala/Art Resource, NY (ART175849).

\footnotetext{
35 See Didron, Christian Iconography, 1: 370.

36 The Book of Malachi 3: 1: "Behold, I will send my messenger, and he shall prepare the way before me: and the Lord, whom ye seek, shall suddenly come to his temple, even the messenger of the covenant, whom ye delight in: behold, he shall come, saith the LORD of hosts."

${ }^{37}$ In Isaiah 53: 7, Christ, the Suffering Servant, is described as a lamb (scapegoat) that is led to slaughter.
} 
According to Voragine's Golden Legend, Adam is associated twice in his life with Tree of Life or the Tree of Knowledge: in his early life as a sinner when he ate a fruit from the tree, disobeying God's dictum; and after his death, forgiven by God, his son Seth is permitted by God to plant on his father's tomb a branch from the holy tree. ${ }^{38}$ From the planted Tree of Life, three branches grew from the trunk. Moses took one for his rod to lead the Israelites out of Egypt. ${ }^{39}$ Vasari depicted a bearded Moses with yellow attire and a lilac cape decorated with a golden brooch that displays an image of a blue sea, referring to Moses' action of using the rod to separate the waters of the Red Sea for the Israelites, allowing them to cross the sea and escape from their Egyptian bondage (Exodus 14: 21) (See Figure 11).

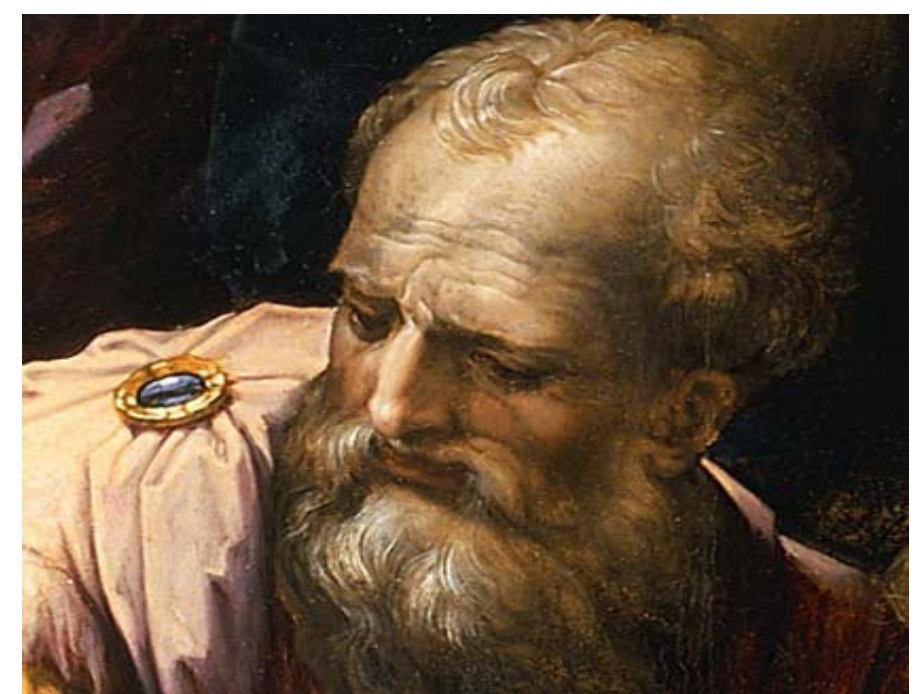

Figure 11. Giorgio Vasari, Moses, det., The Conception of Our Lady, 1540. SS Apostoli, Florence. Photo credit: Scala/Art Resource, NY (ART175849).

After Moses' death, Joshua became the leader of the Israelites (Joshua 1: 1-9; 8: 18-291 and Midrash Numbers Rabbah xiii). Vasari portrayed a fancy image of Joshua, dressed in elegant military garb, including an elaborate blue helmet with a golden lion's mask for the head visor, a golden reclining nude embracing a cornucopia, and a golden sphinx protected by a red plumage crowning the top of the helmet (see Figures 12 and 13). These emblematic ornaments allude to the virtues of fortitude (lion's mask), abundance (cornucopia), and wisdom (sphinx). Joshua's type of helmet recalls the military helmets worn by ancient Roman rulers, as seen in the pedestal of the column on the Apotheosis of Antonius Pius and Faustina of $161 \mathrm{CE}$, in the Cortile delle Corazze at the Vatican Museum (see Figure 14). ${ }^{40}$ According to rabbinical literature, Joshua is a symbol of a faithful and humble spirit. His association with the fig tree is from a verse "Whoso keeps the fig-tree shall eat the fruit thereof" (Midras Numbers Rabbah xii). The implication is that Joshua was anointed to be the ruler of Israel and his people.

\footnotetext{
38 See Didron, Christian Iconography, 1: 367.

39 See Didron, Christian Iconography, 1: 367.

${ }^{40}$ Vasari was also inspired by Renaissance military arms and armors as seen in drawings of Leonardo's Profile of a Warrior in Helmet of 1500, at the British Museum in London and Francesco Salviati’s Helmet of 1545 at the Galleria degli Uffizi in Florence. See Dirk H. Breiding, "Arms and Armor in Renaissance Europe”. In Heilbrunn Timeline of Art History. New York: The Metropolitan Museum of Art, 2000-. http://www.metmuseum.org/toah/hd/rarm/hd_rarm.htm (October 2002).
} 


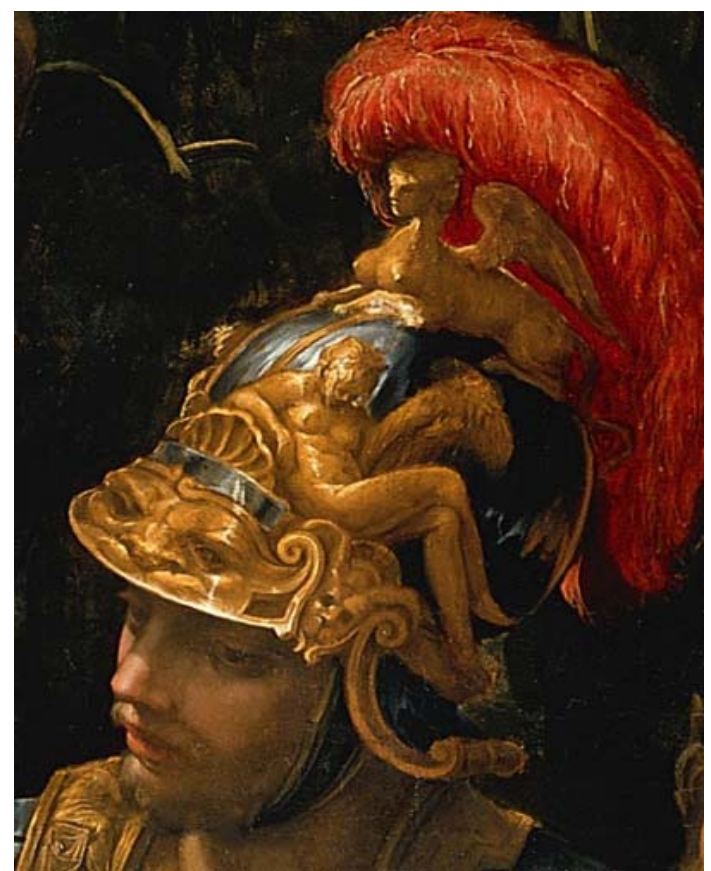

Figure 12. Giorgio Vasari, Joshua, det., The Conception of Our Lady, 1540. SS Apostoli, Florence. Photo credit: Scala/Art Resource, NY (ART175849).

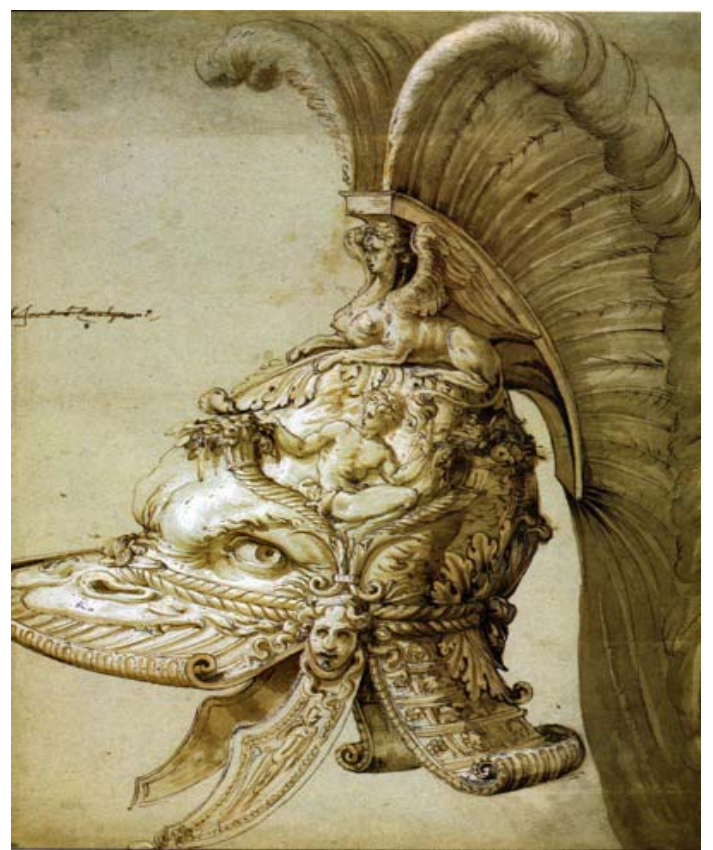

Figure 13. Francesco Salviati (attributed to), Decorative Helmet, 1545, drawing. Galleria degli Uffizi, Florence. Photo credit: Public Domain. Wikimedia Commons. 


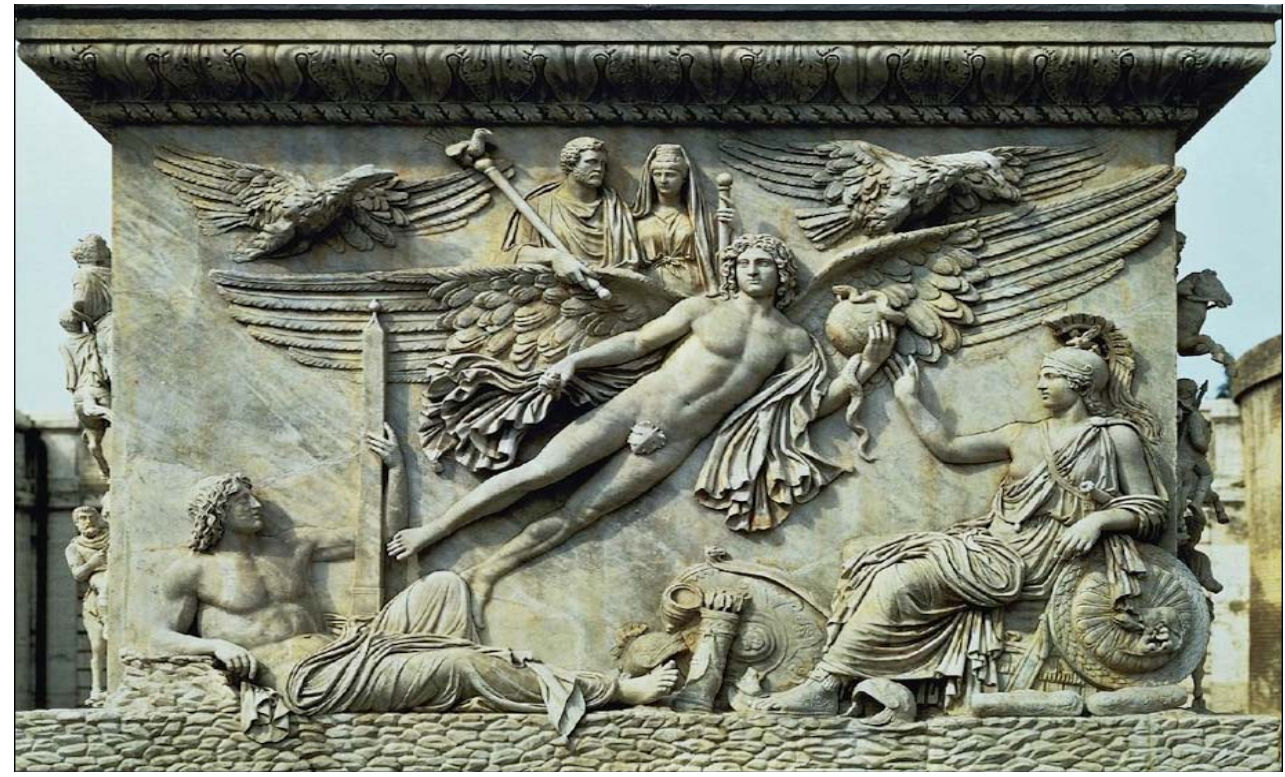

Figure 14. Apotheosis of Antonius Pius and Faustina of 161 CE, Cortile delle Corazze, Vatican Museum. Photo credit: author.

In the painting, Joshua looks at his mentor Moses, while David turns his head to look at the Virgin Mary. Vasari depicted an adult David, holding his musical instrument the harp and crowned with a symbolic keter (the crown of God), alluding to his honor, royalty, and political power as an anointed king of the Israelites. ${ }^{41}$ In Vasari's painting, David and Aaron are the only two figures that are crowned: David's keter (royal crown) differs from Aaron's torah crown, which combines his priesthood role with his kingship status. Also, David and Abraham are the only two figures who are depicted with the same colors: pink for their inner garment and blue for their cloak. It is not by chance that these colors are similar to those seen in the Virgin Mary's attire. Perhaps Vasari was trying to balance stylistically his composition in using similar colorations in the bottom and at the top of the painting as well as connect symbolically the Virgin Mary's natural origin with her messianic mission revealed through the ancestor ship of Abraham and David.

Moreover, David, son of Jesse, is associated with the symbolism of the Tree of Jesse, alluding to the family genealogy of Jesus Christ, from the beginning of the creation and through the Old Testament until the coming of the Messiah. The Church Fathers in their writings and Latin hymns referred to the Tree of Jesse, an allusion to the Tree of Life, as the Davidic vine (radix Jesse); they considered the Virgin Mary (virga ex radice) to be a branch or offshoot of the root of Jesse and her son Jesus as (flos ex virga) to be a flower that blossomed on the branch. ${ }^{42}$ As a 16th-century Christian, Vasari was familiar with the traditional depiction of the Tree of Jesse, where Jesse is shown in a reclined position with a tree springing out of the center of his body, whose branches contain prophets, patriarch, and kings of the Solomon line, thus all the ancestors of Christ. Conventionally in art, at the top of the tree, Mary holding baby Jesus and angels are represented, an allusion to gifts of the Holy Spirit as seen in the North transept mosaic in Saint Mark in Venice of the Bianchini Brothers' Tree of Jesse based on a design of Francesco Salviati of 1540 (see Figure 15).

\footnotetext{
41 See Stuart A. Cohen, "Keter as a Jewish Political Symbol: Origins and Implications,” in Jewish Political Studies Review 1.1-2 (Spring 1989), 39-62.

42 See http://campus.udayton.edu/mary/meditations/jessetree.html.
} 


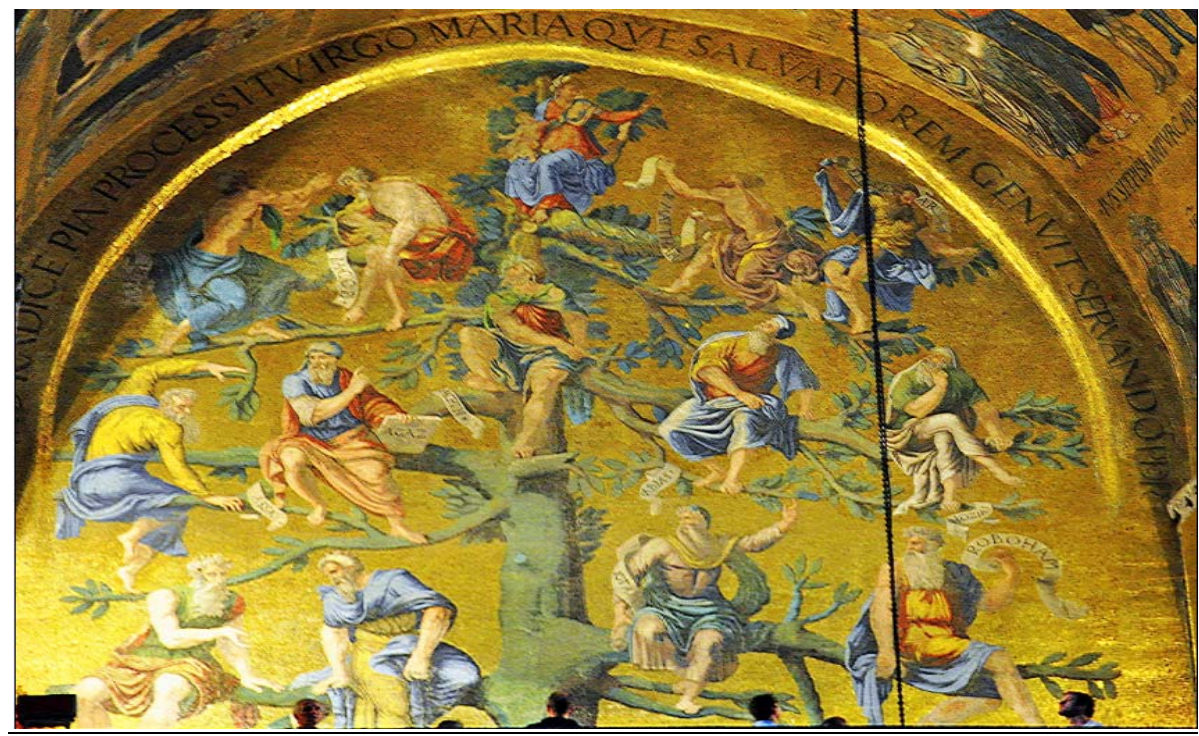

Figure 15. Bianchini Brothers, Tree of Jesse, mosaic, 1540. (Based on a design of Francesco Salviati, 1540). North transept, Saint Mark, Venice. Photo credit: author.

In his painting, however, Vasari transformed the traditional group image at top of the tree by depicting a solo image of the Virgin Mary, focusing on her human and divine natures. She is portrayed in gestation, with full breasts and abdomen, which emphasizes her nature and her motherhood, while her modest and pious attitude reveals her spiritual essence and the divine significance of having been chosen to be the mother of God (see Figure 16). Vasari also replaced the recumbent Jesse at the foot of the tree with the reclining figures of Adam and Eve. He selected from the Old Testament some of the ancestors of Christ. He not only reduced the figures in number, but also depicted them tied up to the branches of the tree, thus associating them as Christ's ancestors in the Tree of Jesse with the symbolism of the Tree of Life, Tree of Knowledge, and the Tree of Good and Evil. ${ }^{43}$

The Virgin Mary becomes the portal to the Davidic line from Adam, through Abraham, Isaac Jacob, Moses Aaron, Joshua, and David. Samuel and John the Baptist both prophesized the coming of the Messiah, prepared for God's anointment, and built the foundation for Christ's temple/church (1 Sam. 1: 15, I Sam. 1: 20, and Luke 1: 76-79). ${ }^{44}$ Hence, in The Conception of Our Lady, Vasari created two designs based on the shape of the triangle. The first triangle composed with the Virgin Mary in the clouds alludes to King Solomon's seal, and the second shape composed of two triangles joined to form a star refers to the Star of David, Solomon's son. In this stellar format are included those figures who participated in the terrestrial world (natural realm) but, through the Virgin Mary, ascended into a celestial plateau (metaphysical world), the realm of God (see Figure 16).

\footnotetext{
${ }^{43}$ The artistic motif of the Jesse tree is known from the beginning of the eleventh century and disappeared in the early seventeenth century. See http://campus.udayton-.edu/mary/meditations/jessetree.html.

44 See Rev. Harry Colquhoun, The Gospel Message in Luke's Story of the Nativity, Chapter 2, http://www.maybole.org/community/churches/chapter2.htm.
} 


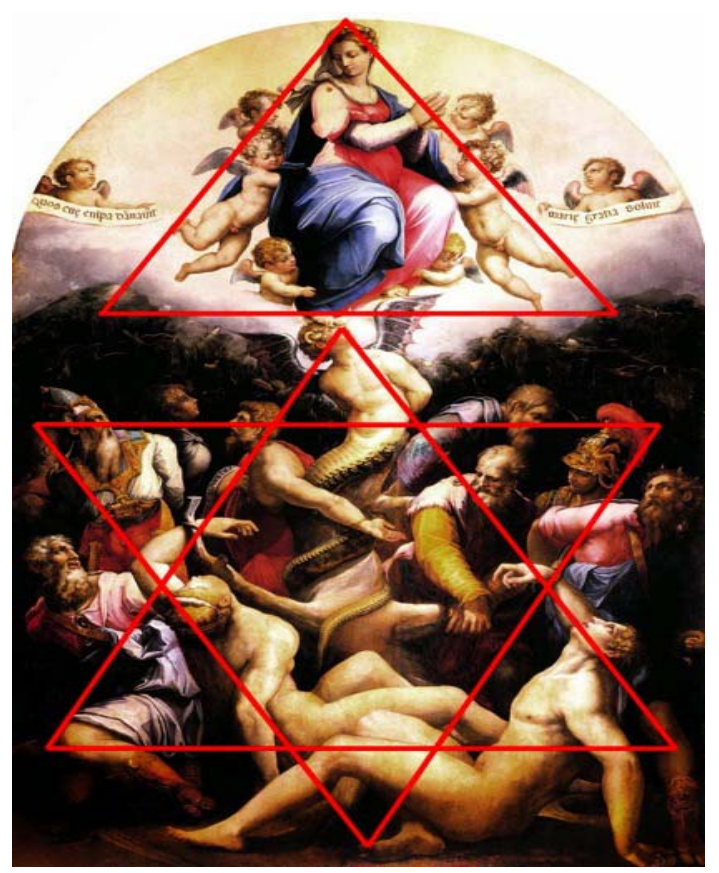

Figure 16. Cheney’s Symbolic Star of David from Giorgio Vasari, The Conception of Our Lady, 1540. SS Apostoli, Florence. Photo credit: author.

\section{Second Separation: Metaphysical Realm}

In this second separation in the painting, the metaphysical realm, the depiction of heaven is represented by the appearance of the Virgin with her entourage of visible angels and cherubs who surround her, creating a nimbus, as second group of angels, less visible, form a golden crown. Outside the nimbus, two cherubs accompany the Virgin, holding a scroll that announces her divine presence and the spiritual salvation for humankind: "Eve's committed fault was paid with the grace of Mary." One scroll held by one angel provides the natural cause for the event, Quos Eve culpa davit (Those whom Eve's fault condemned), while the other inscription, held by another angel, alludes to a metaphysical effect and the formation of a joyous resolution with the presence of the Virgin, Mariae Gratiae Solvit (Mary's grace set [us] free). The presence of the cherubs is significant, for they were guardians of the Tree of Life, particularly after the casting out of Adam and Eve from Paradise (Genesis 3: 20-24).

In his article on Giorgio Vasari's Allegory of the Immaculate Conception, Dónal O’Connor provided several interpretations and references for these inscriptions, noting discrepancies among the quotations in Vasari's drawings and paintings, ascribing some to Old Testament sources such as Solomon's Songs of Solomon 4: 7: "Tota pulchara es, amica mea, et mascula non est in te” (You are all beautiful, my love, and there is no flow in you), ${ }^{45}$ while tracing another inscription, like in the painting in SS. Apostoli, to Adversus Haereses, where Bishop Saint Ireneaus of Lyons (130-200) discussed the relationship between Eve and the Virgin Mary. ${ }^{46}$

O'Connor elaborated further on the connection between Eve and Mary (Eva/Ave), as noted in other Latin inscriptions in Vasari's second version for Altoviti’s Roman villa, which is presently at the Uffizi (inv 1524).

\footnotetext{
${ }^{45}$ See O’Connor, “Giorgio Vasari’s Allegory of the Immaculate Conception,” 169-77, 172.

${ }^{46}$ See O’Connor, “Giorgio Vasari’s Allegory of the Immaculate Conception,” 172.
} 
Vasari executed this second commission as a smaller copy while residing as a guest in Altoviti's villa in 1542. Thecartellini held by the angels state: Quod Eva tristis abstuli (What man had lost in hapless Eve) and Tu reddis almo germine (Thy [Mary] sacred womb to man restores). These verses may be read together as "By the fair blossom you [Mary] restored; what lamentable Eve decayed," whose source is from the hymn to the Virgin Mary,O Gloriosa Domina (O Heaven's Glorious Woman). ${ }^{47}$ For the new Latin inscriptions in the Uffizi version, Vasari probably relied on Altoviti's humanist circle, whose members of this Roman religious intelligentsia were the Cardinal Alessandro Farnese (1520-1589) and his scholarly advisors and prelates, Annibale Caro (1507-1566), Paolo Giovio (1483-1552), and Claudio Tolomei (1492-1556).

The Virgin Mary's celestial appearance in the clouds surrounded by the heavenly angelic court delivers the message to the viewer of God's mandate as inscribed in the scrolls. In John of Patmos' Book of Revelation, there is an allusion to this event: "A woman robed with sun, beneath her feet the moon, and on her head a crown of twelve stars," a familiar Christian reference known to Canon Pollastra as well as to the religious devotee Vasari. Although 12 stars are not depicted in the painting, Vasari has interpreted the Evangelist John's description of brilliant stars in painting the Virgin Mary bathed in radiant golden light, alluding to the significance of her name, Mary, meaning "the beautiful or the perfect one". ${ }^{48}$

Vasari portrayed her partaking of the contemplative or spiritual essence, a pious attitude-praying hands and cast down eyes — clothed with modest attire, and partially veiled, although some of her blond, coiled tresses are revealed. An ornament with a golden daisy is in the center of her coiffure. This simple flower, marguerite, is a symbol of her humility, grace, and purity. The Virgin Mary looks calmly over her shoulder at the golden clasp decorating her attire, which is in the shape of a rose and contains a ruby, a subtle but ingenious allusion to the Virgin Mary as the rosa mystica (mystical rose), that is, a rose without thorns (see Figure 17). The Marian symbol or the rosa mystica dates from the fifth century with Sedulius Caelius. He was probably the first to call Mary a "rose among thorns" (Carmen paschale II, 28-31), paradoxically alluding to her innocence untouched by evil. ${ }^{49}$ Although scholars have mentioned in their writings the association of the Immaculate Conception with the symbolism of the rose, they have not noticed how Vasari visualized it in the Virgin's attire, particularly in her brooch.

\footnotetext{
${ }^{47}$ See O’Connor, “Giorgio Vasari’s Allegory of the Immaculate Conception,” 173, for his translation of the Latin inscriptions: "What sad Eve took away, You [May] have restored by your fair offspring." The poem derives from the Bishop of Poitiers, Venantius Fortunatus' (530-609) Quem terra, pontus, aethera (The God Whom Earth and Sea and Sky), a popular hymn employed in lauds and readings on the blessed Virgin Mary. Another possible translation is "What man had lost in hapless Eve, thy [Mary] sacred womb to man restores." See The Liturgia Horarum, Common of the Blessed Virgin Mary, trans. R. F. Littledale and others, http://www.preces-latinae.org/-thesaurus-/BVM/OGloriosa.html.

${ }^{48}$ For the explanation of the name of Mary, see Kevin Night, "Dedicated to the Immaculate Heart of Mary,” 2012, http://www.newadvent.org/cathen/15464a.htm.

49 J. C. Tierney, ed., 10/26/2010, http://campus.udayton.edu/mary/questions/yq/yq70.html, notes: "Frequent Marian references to rose and rosebush were made in middle ages with reference to Isaiah 11:1 ("a shoot shall sprout from the stump of Jesse/and from his roots a bud shall blossom”).” This typology is found Tertullian (Adv. Judaeos, 9) and Ambrosius (Exp. Gr. Luc. II, 24). For these authors, the root is a reference to the Davidic genealogy, the sprout (virga, bush) is Mary, and Christ is the flower (rose). Medieval authors had a second source for their use of mystical rose: the verse from Sir. 24: 14 ("like a palm tree in Engedi, like a rosebush in Jericho"), which makes reference to God-graced fertility and growth, again a reference to the mysterious generation of Christ from the womb of Mary. It is based on these two traditions that the expression rosa mystica was coined by the author of the Litanies of Loreto and subsequently was used in hymns ("Es ist ein Ros ...") and art (center of the labyrinth of Chartres).

Mary's mystery is that of her virginal motherhood. The invitation of the lemma: "Let us crown ourselves with rosebuds" (Wisdom 2: 8) is addressed to all. Stefan Geissel, Geschichte der Verehrung Marias im 16. und 17. Jahrhundert. Ein Beitrag zur Religionswissenschaft und Kunstgeschichte (Freiburg: Herder Verlag im Breisgau 1910), 250.2 See http://digilander.libero.it/mariaoggi/simbologia.htm\#maria.
} 


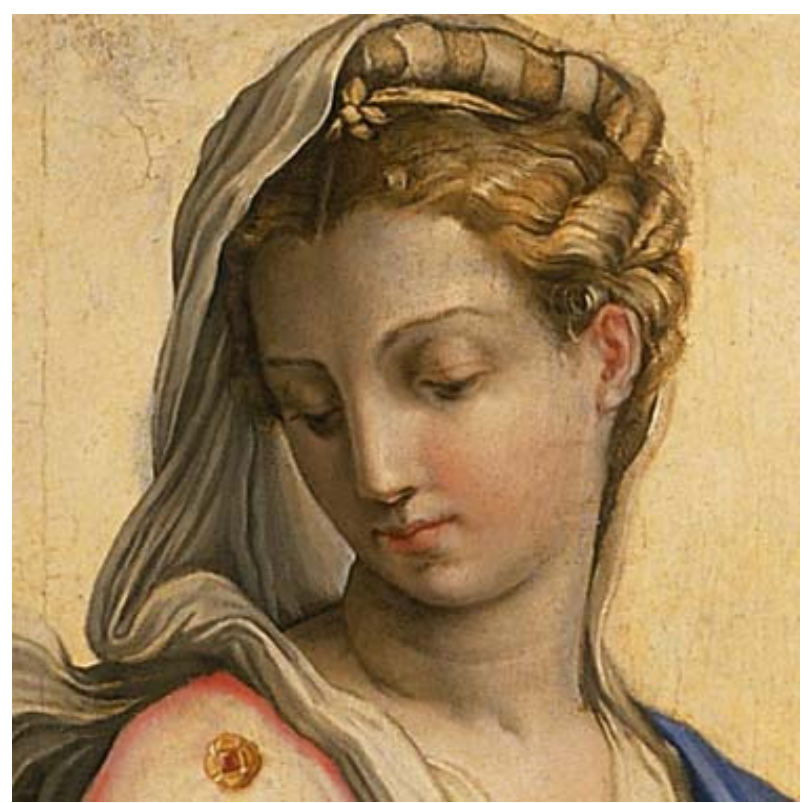

Figure 17. Giorgio Vasari, Virgin Mary, det., The Conception of Our Lady, 1540. SS Apostoli, Florence. Photo credit: Scala/Art Resource, NY (ART175849).

Vasari elaborated further on this metaphorical division between the metaphysical and natural realms in depicting different types of female figures in his painting. For example, the Virgin Mary (Ave) partakes of the celestial realm, while the Serpent and Eve (Eva) are members of the earthly realm. In the natural realm, Vasari depicted the physicality of nature by portraying Eve reclining nude on earth. The modest and clothed Virgin Mary, the new Eva or Ave, looks down to the unveiled and nude Eve or Eva. Several scholars have studied the interplay of their names, Eva being read in reverse as Ave, thus referring to the Virgin Mary, Ave Maria. ${ }^{50}$ With this name Ave Maria, the messenger of God, the archangel Gabriel, saluted the Virgin Mary in the moment of her conception.

Eva represents natural naturans or mother of all things that is the material aspect of life, while the Virgin Mary, the mother of the souls, represents the spiritual aspect of life. Tied up to a fig tree, a source of her entanglement, Eve and her companion, Adam, both look up at the Virgin Mary, seeking forgiveness and hoping for redemption and salvation. The design of their reclining nude bodies in the form of a half a moon parallels the shape of the crescent moon that the Virgin Mary is stepping on or crushing into, an action that alludes to her mission of freedom and triumph. Her granted divine grace will provide liberation from human's sin. Vasari’s composition comprises a hopeful Eve, in the nude, tied up and at the feet of a fig tree, turning her eyes toward the heaven for absolution.

In The Conception of Our Lady, the tree depicted is the biblical fig tree, ${ }^{51}$ a conduit of both good and evil. The fig tree is composed of two genders-male (caprificus or wild) and female (cultivated). ${ }^{52}$ It is a

\footnotetext{
${ }^{50}$ See H. Diane Russell with Bernadine Barnes, Eva/Ave: Women in the Renaissance and Baroque Prints (Washington, DC: National Gallery of Art, 1990), 113-29; and Antonio de Sousa de Macedo, Eva e Ave (Portugal 1676), repr. and trans. in Spanish in 1882 as Eva, y Ave, o, María triunfante: teatro de la erudición, y filosofía cristiana en que se representan los dos estados del mundo, caido en Eva y levantado en Ave (University of Michigan Library, Reprint editions, 2011).

51 See Old Testament, Deuteronomy 8: 8-10, alluding to a positive aspect of the fig tree suggesting the Promised Land and prosperity. In the New Testament, Luke 13: 6-9; Luke 21: 29-33, Matt. 24: 32-36, and Mark 13: 28-32, alluding to Christ's parable of the blooming tree without fruit, alluding to the negative aspect of the fig tree, a barren fig tree.

${ }^{52}$ See Zohary, Plants of the Bible, 58.
} 
hermaphrodite fruit-plant: the male component is called caprificus and it is wild in nature, whereas the female component or ficus carica is fruitful in nature. In the painting, the angelic horned figure resembles a capra demon or a humanoid with goat (capra) attributes, such as the horn. ${ }^{53}$

Coiled around the tree trunk is a hybrid human form, acapra demon, composed of two parts: above the hips the creature depicts a male winged angel, while below, the rest of the form is the tail of a snake, whose scales or snakeskin reflect the design of a fig tree, demonstrating the snake's ability to camouflage into a natural form (see Figure 18). The tail twists vigorously around the tree trunk, whose branches keep captive the offspring of Adam and Eve and ancestors of Mary. The angelic-evil figure is paradoxically portrayed with golden hair but decorated with a horn; it has an innocent face and classical torso but a serpentine scaled body; its angelic wings are covered with eyes like the seraphim ${ }^{54}$ but allude to the bat's wings of the devil. ${ }^{55}$ These wings, containing heterotopic eyes, may be a symbol of night with multitudes of stars or of darkness and destruction, as the bat's wings of Satan. ${ }^{56}$ The serpent is also paradoxically a creature representing the embodiment of Satan-Drago as well as Lucifer, the most beautiful star (angel). ${ }^{57}$ The serpent is bound to the tree, and its roots partake of the earthly and underground worlds, unlike the Virgin Mary who freely floats in the clouds, residing in a celestial world. Unlike the large serpent's wings, the angels that accompany the Virgin Mary have short wings, which are decorated with pink and blue colors, reflecting the same colors of her attire and, hence, a further allusion to her celestial realm.

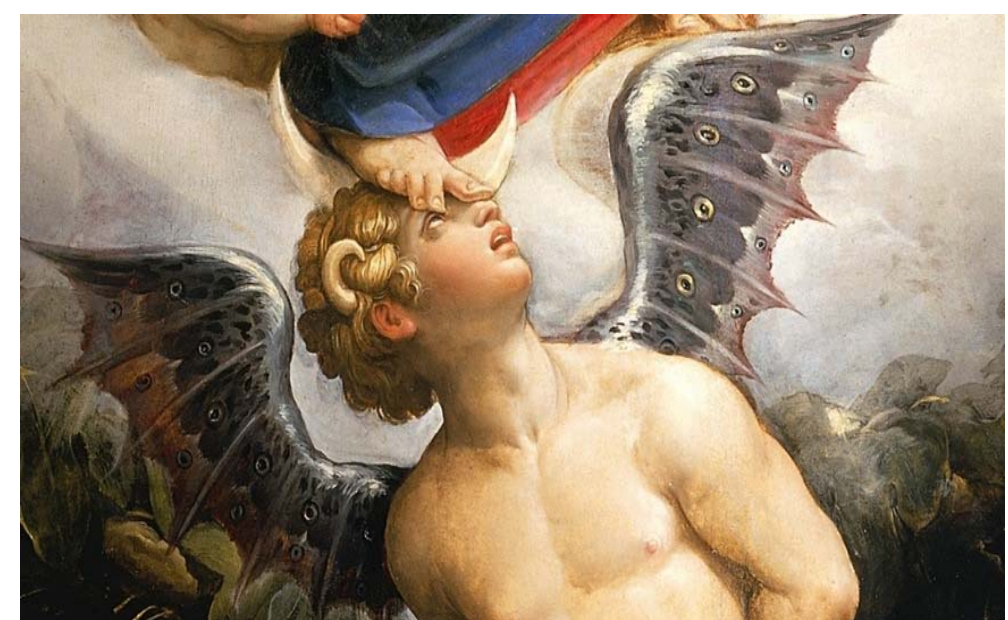

Figure 18. Giorgio Vasari, Capra demon, det., The Conception of Our Lady, 1540. SS Apostoli, Florence. Photo credit: Scala/Art Resource, NY (ART175849).

\section{The Fig Tree and the Fir Tree}

Vasari connected the natural world, earth, with the metaphysical world, heaven, by means of a vertical axis, a tree or arbor of life, which is an image of both axis mundi (world-axis) and imago mundi

\footnotetext{
53 See the sacrificial ritual during the Roman festival, called Nonae Caprotinae, in honor of the goddess Juno Caprotina (Juno the Goat) and the climbing of the wild fig-tree.

${ }^{54}$ Seraphim are angels of Divine Love symbolized by all the eyes in their wings; see Isaiah 7: 1-3 and Ezekiel Chapter 1.

55 See John, Revelation 4: 6-8.

${ }^{56}$ See J. E. Cirlot, A Dictionary of Symbols (New York: Philosophical Library, 1962), 96-97; and Hans Biedermann, Dictionary of Symbolism: Cultural Icons and the Meanings Behind Them (New York: Oxford University Press, 1992), 30.

${ }^{57}$ See John, Revelation 1: 20.
} 
(world-image) ${ }^{58}$ The depiction of the fig tree relates to several biblical trees: The Tree of Life, the Tree of Knowledge, and the Tree of Jesse as well as the Tree of Good and Evil. In Renaissance art, the latter is best visualized in Berthold Furtmeyer's (1435-1506) The Tree of Death and Wood of Life of 1489, an illuminated folio (Clm 5708-712, folio 6 in vol. 3) from the Salzburg Missal, a beautiful manuscript (Clm 5708-712, 5 vols.) at the Bayerische Staatsbibliothek in Munich (see Figure 19). The imagery is divided into two parts and united in the center with a fig tree. The left side portrays the Virgin Mary, crowned and dressed as the Queen of Heaven. She obtains fruits (hosts) from the fig tree, alluding to the spiritual food for faithful Christians. The transformation of the fruit into a host refers to the Christian dogma of the transubstantiation, where after His death, His body is miraculously transformed into bread (the host) during the sacrifice of the Mass; hence the depiction of the Crucifixion in the foliage of the tree.

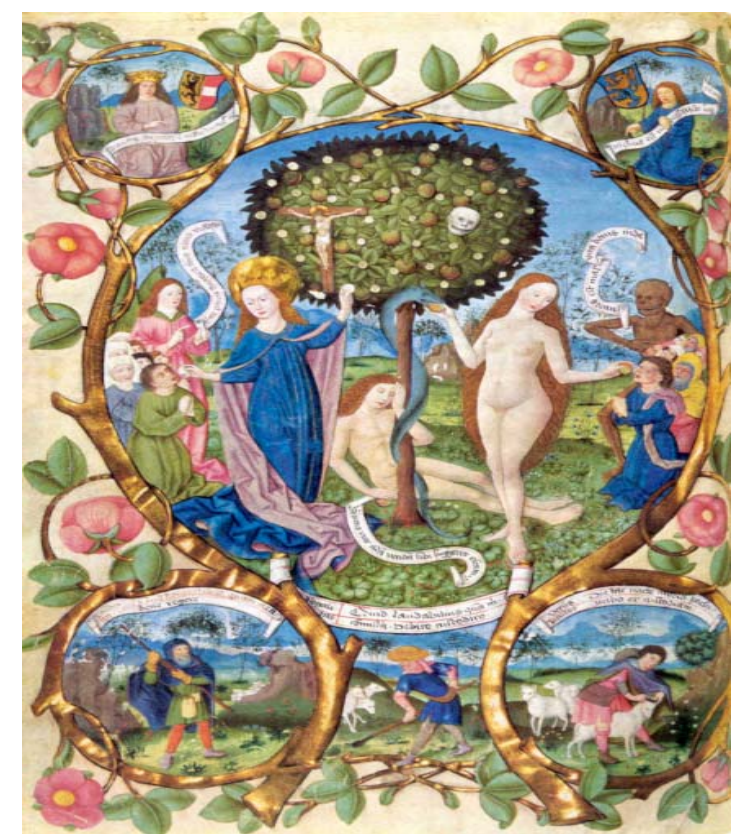

Figure 19. Berthold Furtmyer (1435-1506), The Tree of Good and Evil, in the manuscript of Salzburg Missal, 1489 Clm 5708-712, folio 6 in vol 3 (Clm 5708-712, 5 vols). Bayerische Staatsbibliothek, Munich. Photo credit: Public Domain. Wikimedia Commons.

In contrast, on the other side of the tree, a nude Eve obtains fruits to feed her followers from the mouth of a Serpent, who is crawling on the tree truck. The depiction of a skull (death) in the foliage of the tree alludes to the decomposition of the fruit. With the assistance of the Skeleton of Death, who is hiding behind the procession of the devotees and guiding them to eat from the evil tree, Eve is poisoning her devotees by feeding them putrid figs. In Renaissance religious iconography, the fig tree has been symbolically connected with the Tree of Life, the Tree of Knowledge, and the Tree of Good and Evil.

In this essay, I briefly considered Vasari's association of the fig tree to the Davidic line of Christ and its connection to the Virgin Mary. However, I wish to make another point connecting Vasari's selection of the painted tree with his travels and the enterprises of his patron Altoviti, in particular, their staying at the Camaldoli monastery.

\footnotetext{
58 See J. C. Cooper, An Illustrated Encyclopaedia of Traditional Symbols (Oxford: Thames and Hudson, 1978), 176; and Cirlot, A Dictionary of Symbols, 329-29.
} 
Camaldoli is a historical place for Vasari (see Figures 20a and b). Here he met his patron Altoviti for the first time, and here he received the commission to paint The Conception of Our Lady. Vasari projected in his painting interrelations between the natural and the metaphysical realms with his personal life. For example, when he visited the Camaldoli monastery and its forest, he experienced the power of nature in seeing the majestic fir trees. For the fig tree in the composition of his The Conception of Our Lady, he imitated the form of a fir tree, which has a robust tree trunk and thick projecting branches (compare Figures 20b with 2). He also connected the natural power of vegetation with the spiritual biblical references of the Tree of Life and the Tree of Jesse, since the fir tree is a symbol of endurance, joy as well as an allusion to the Davidic lineage of Christ. ${ }^{59}$

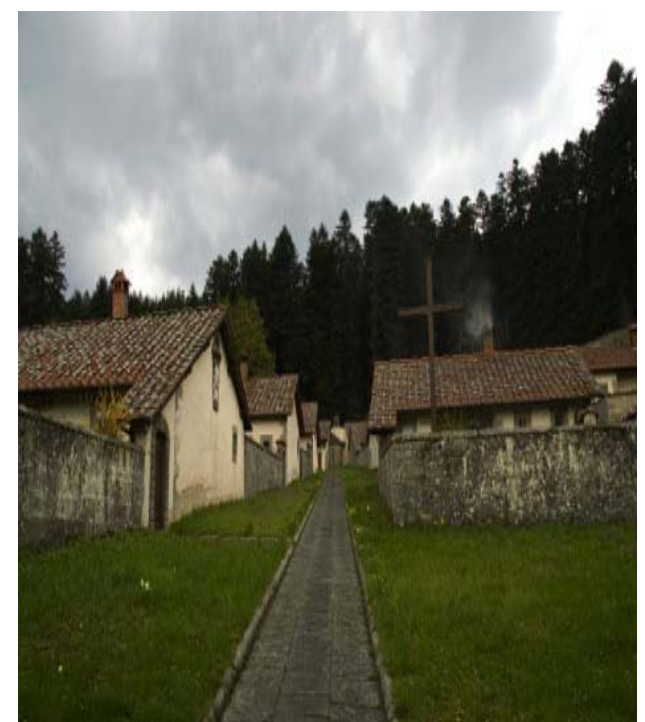

Figure 20. a. Camaldoli Monastery, Vicinity of Arezzo, Italy. Photo credit: author.

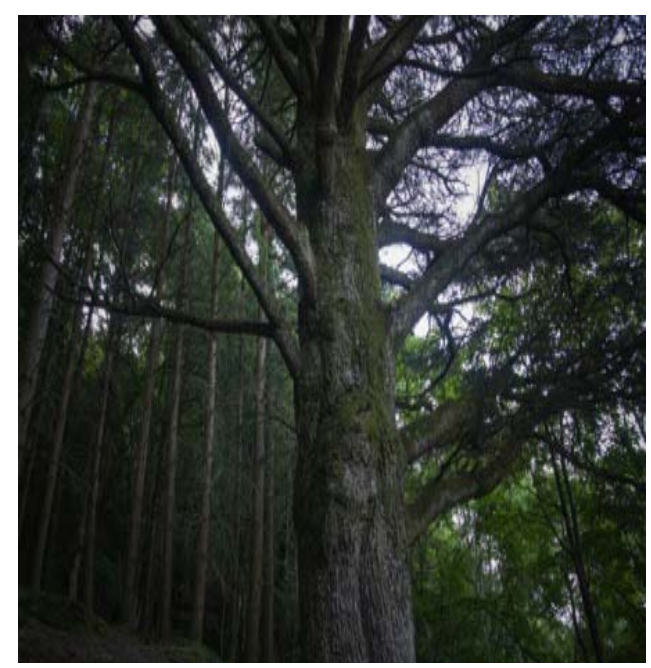

Figure 20. b. Fir Tree Forest, Camaldoi Monastery, Vicinity of Arezzo, Italy. Photo credit: author.

\footnotetext{
${ }^{59}$ See the biblical symbolic citations in Dr. Joe Temple, "Like a Fir Tree," http://www.livingbiblestudies.org/study/JT9/005.html. For example, as a symbol of God's house, Psalm 104: 7, "as for the stork, the fir trees are her house"; as a symbol of joy and the Davidic line, II Samuel 6: 5, “And David and all the house of Israel played before the LORD on all manner of instruments [now notice] made of fir wood, even on harps, and on psalteries, and on trimbles, and on cornets, and on cymbals"; and as goodness, Hosea 14: 8, "I am like a green fir tree.”
} 
Furthermore, Vasari was aware of his patron's enterprise of purchasing Camaldolense fir trees for the Church, for building the main Christian basilica, Saint Peter's, in Rome. Hence, at a practical level, he paralleled the commercial and business labors of his patron, Altoviti, with his own labors (fatiche) in completing the commission, the painting of The Conception of Our Lady. Vasari continued this metaphor, but at a spiritual level. In the Bible, Old Testament prophets cited the fir tree as being associated with the house of God. In Psalm 104: 17, for example, "as for the stork, fir trees are her house.” In this passage, the fir tree is metaphorically connected with the house of God. The stork caring for and depositing her young among the branches of the fir tree parallels the Virgin Mary's conception and dwelling in the house of God. In his imagery, Vasari assimilated the biblical passage in placing at the top of the tree a pregnant Virgin Mary, alluding to her carrying a precious and holy fetus and residing in the celestial house of the Lord. Other biblical references emphasize the natural qualities of fir tree, evergreen color physical endurance, which become symbols of resilience and longevity. ${ }^{60}$

With his Christian upbringing and in his writings, ${ }^{61}$ Vasari paid homage to the Virgin Mary, the Mother of God and the spiritual mother of all Christians, associating the purpose of his patron's religious mission with the Christian function of building a magnificent edifice for the glory of the Virgin Mary's son, Christ-God. Vasari visualized these meanings in The Conception of Our Lady by paralleling the axial movement of the fig tree with a design of the Latin cross (see Figure 21). Furthermore, he created two parallelisms: (1) the Latin cross design in the painting with the Latin cross design of the ground floor plan in St. Peter's (see Figure 22), and (2) the significance of the focal point of the crossing in a Christian church by placing in the painting the Virgin Mary at the intersection of the Latin cross design (compare Figure 22 and 21). Hence, the Virgin Mary emerges as a symbol of the heart of the cross. She becomes the spiritual leader, the carrier of divine grace, and the portal for Christians to receiving divine grace, reach salvation and being able to contemplate God in Paradise.

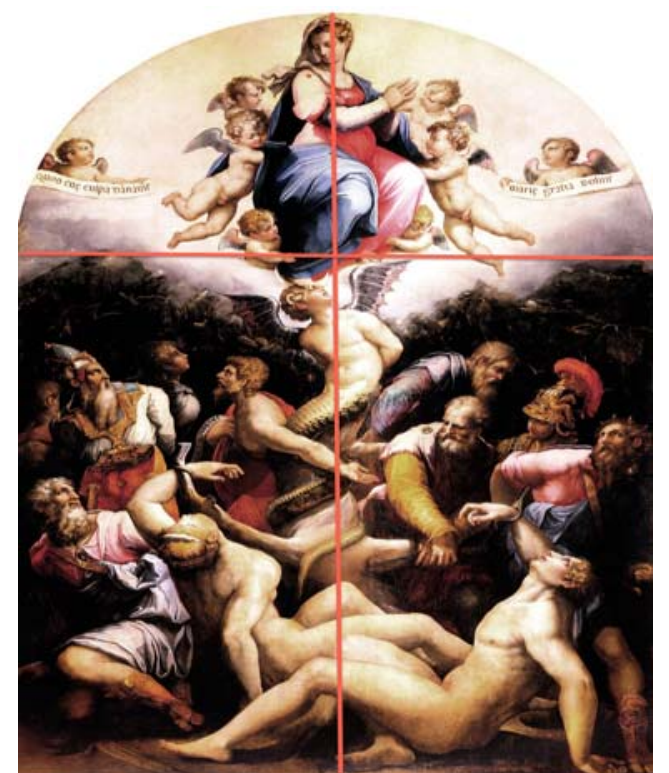

Figure 21. Cheney’s Latin Cross design from Giorgio Vasari, The Conception of Our Lady, 1540. SS Apostoli, Florence. Photo credit: author.

\footnotetext{
60 Ibid.

${ }^{61}$ See Filip Malesevic, “Artisti di Santità”; Tridentine Influences in Giorgio Vasari’s Vite, forthcoming article. I am grateful to Prof. Malesevic, University of Fribourg, Switzerland, for providing me with a copy of his essay.
} 


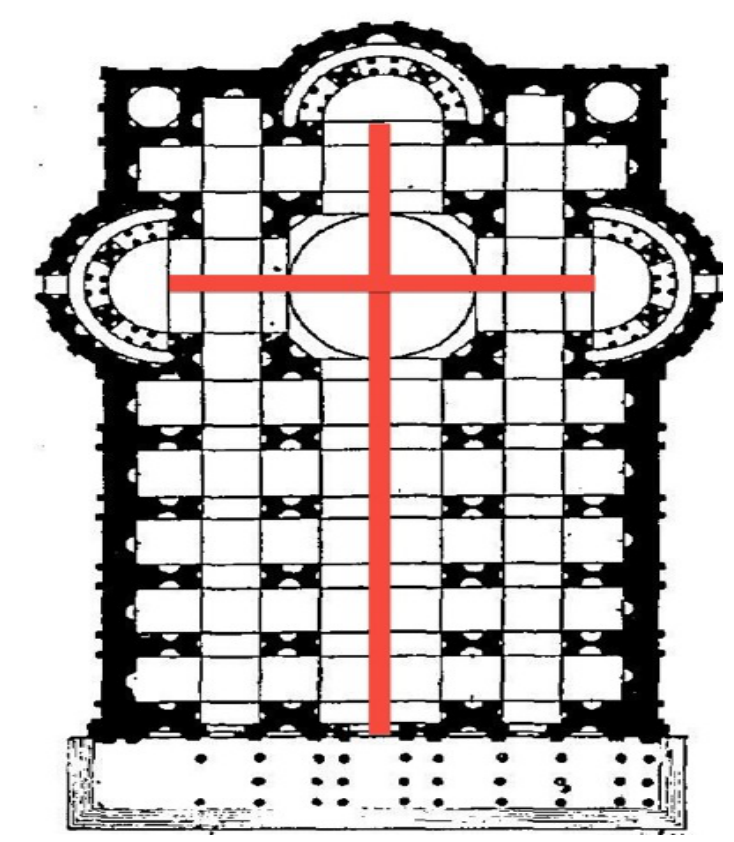

Figure 22. Raphael, Saint Peter’s Plan, 1520. Vatican. Photo credit: Public Domain. Wikipedia.org.

Since the Middle Ages, Church Fathers have associated the image of the Virgin Mary with numerous natural and divine allusions. As the mother of God, for example, significations connect her with her Son's sacrifice and death, such as the chalice, a vessel for Christ's blood, and the cross, the instrument of her Son's Crucifixion. ${ }^{62}$ As the Queen of Heaven, she becomes a personification of wisdom (sophia), a seat of wisdom (sede sapienza), and the Church (ecclesia). ${ }^{63}$ As the Virgin Mary partakes metaphorically of the physical and metaphysical realms, she is identified with the essence of beauty, goodness and perfection. These realms are visualized in the shape of a circle, as allusion to cosmic eternity. ${ }^{64}$ Circularity is a symbol of perfection and infinity in the celestial sphere, contrasting with the rotation of the earth in the terrestrial cycle (see Figure 23).

In the imagery of the Virgin Mary, Vasari endowed her with physical and spiritual beauty, revealing her purity of conception and divine maternity. For him, the depicted image of the Virgin Mary is of a human and a divine mother impregnated with life. Like a fruit on a tree that has achieved maturation from an earlier planted seed, the Virgin Mary's placement at the top of the fig tree alludes to her conceiving the most precious fruit, Christ, the Son of God. Her miraculous state of motherhood reveals her divine motherhood, the Christian allusion that she is the mother not only of Christ but also of His followers; hence, she becomes of mother of His church. She is the vehicle of God's divine plan and wisdom. Thus, Vasari's Virgin Mary in the Conception of Our Ladyat SS. Apostoli embodies beauty, divine wisdom, sophia, and divine grace.

\footnotetext{
62 See Liana De Girolami Cheney, “Giorgio Vasari: Il Trasporto di Cristo,” in Artibus et Historiae (Fall 2012), 3-20.

${ }^{63}$ See James Custinger, “The Virgin,” in Sophia, The Journal of Traditional Studies 6.2 (2000); and for the various associations of the Virgin Mary as a model of the Church, see http://campus.udayton.edu/mary/resources/documents/docs4-2.html; William Tronzo, ed., St. Peter's in the Vatican (Cambridge: Cambridge University Press, 2005), 227; and Adolf Katzenellenbogen, The Sculptural Programs of Chartres Cathedral: Christ, Mary, Ecclesia (Baltimore, MD: Johns Hopkins University Press, 1959), 56-60.

${ }^{64}$ See note 26, JCJ Metford, Dictionary of Christian Lore and Legend (London: Thames and Hudson, 1983), 68; Cirlot, A Dictionary of Symbols, 44-46; and Biedermann, Dictionary of Symbolism: Cultural Icons and the Meanings Behind Them, 69-72.
} 

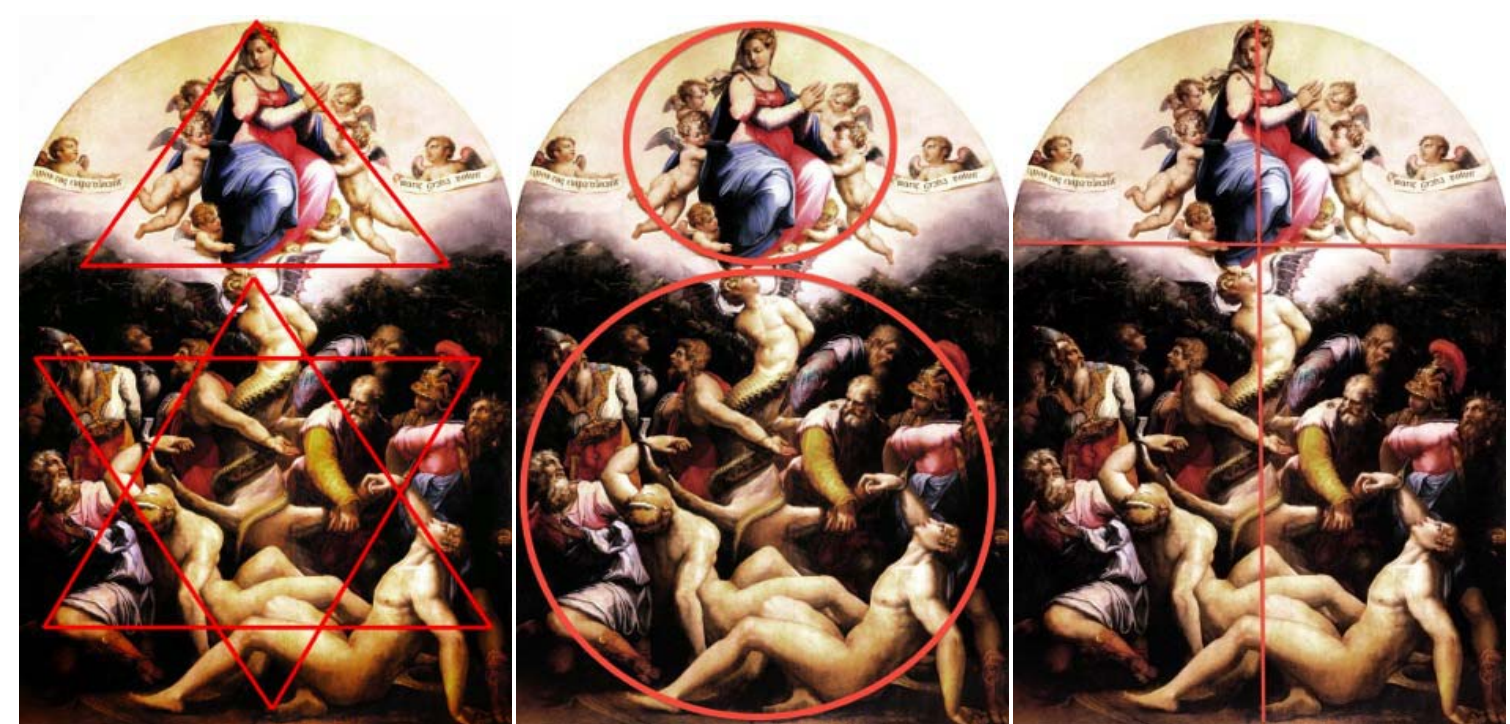

Figure 23. Cheney’s Symbolic Designs from Giorgio Vasari, The Conception of Our Lady, 1540. SS Apostoli, Florence. Photo credit: author.

\section{References}

Anderson, R., \& Anderson, G. (1966). The Jesse tree: The heritage of Jesus in stories and symbols of advent for the family. Philadelphia, PA: Fortress Press.

Barocchi, P. (1964). Vasari Pittore. Milan: Club del Libro.

Bettarini, R., \& Barocchi, P. (Eds.). (1987). Giorgio Vasari, Le vite de'più eccellenti pittori, scultori e architettori (Le lives of the most excellent painters, sculptors and architects) (Vol. 6). Florence: S.P.E.S.

Biedermann, H. (1992). Dictionary of symbolism: Cultural icons and the meanings behind them. New York: Oxford University Press.

Bocchi, F. (1591). Le Belezze della città di Firenze (The beauties of the City of Florence). Florence: B. Sermatelli.

Borghini, R. (1584). Il Riposo. Florence: Giorgio Marescotti.

Breiding, D. H. (2002). Arms and Armor in renaissance Europe. In Heilbrunn, Timeline of art history. New York: The Metropolitan Museum of Art. Retrieved from October, 2002, http://www.metmuseum.org/toah/hd/rarm/hd_rarm.htm

Caneva, C. (1980). Giorgio Vasari. In Il Primato del Disegno. Florence: Centro Di.

Chastel, A. (1975). Marsile Ficin et L'Art (Marsilio ficino and art). Geneva: Droz.

Cheney, L. De G. (2007). Giorgio Vasari’s teachers: Sacred and profane art. London/New York: Peter Lang Publishing, Inc.

Cheney, L. De G. (2012). Giorgio Vasari: Il Trasporto di Cristo. In Artibus et Historiae (Fall 2012) 3-20.

Cheney, L. De G. (2012). Giorgio Vasari’s prefaces: Art and theory. New York/London: Peter Lang Publishers.

Cheney, L. De G. (2013). Giorgio Vasari’s the dream of Jacob. In L. De G. Cheney \& Y. Even (Eds.), Vasari in Context (ERIC Special Edition, pp. 7-25). Explorations in Renaissance Culture Journal. Saint Louis, MO.

Cirlot, J. E. (1962). A dictionary of symbols. New York: Philosophical Library.

Clubb, L. G. (2010). Pollastra and the origins of the twelfth night. London: Ashgate.

Clubb, L. G., \& Black. R. (1993). Romance and Aretine humanism in Sienese comedy. Siena: La Nuova Italia.

Cohen, S. A. (1989). Keter as a Jewish political symbol: Origins and implications. Jewish Political Studies Review, 1(1-2), 39-62.

Colquhoun, Rev. Harry. (2010). The Gospel message in Luke's story of the nativity, Chapter 2. Retrieved from http://www.maybole.org/community/churches/chapter2.htm

Cooper, J. C. (1978). An illustrated encyclopaedia of traditional symbol. Oxford: Thames and Hudson.

Corti, L. (1981). Giorgio Vasari. Florence: Edam.

Custinger, J. (2000). “The Virgin,” in Sophia. The Journal of Traditional Studies, 6(2).

de Sousa de Macedo, A. (1676). Eva e Ave. Portugal, repr. and trans. in Spanish in 1882 as Eva, y Ave, o, María triunfante: teatro de la erudición, y filosofía cristiana en que se representan los dos estados del mundo, caido en Eva y levantado en Ave. University of Michigan Library, Reprint editions, 2011. 
De Vere, \& G. Du C. (Trans. and Ed.). (1979). Giorgio Vasari, lives of the most eminent painters, sculptors and architects (Vols. 1-3). New York: N. Abrams, Inc.

del Vita, A. (Ed.). (1938). Il Libro delle Ricordanze di Giorgio Vasari (Giorgio Vasari’s memories). Arezzo: Tipografia Zelli.

Didron, A. N. (1851, repr. 965). Christian iconography (Vols. 1-2). New York: Frederick Unga.

Ellis, L. H. Jr. (Trans. and Ed.). (2007). Raffaello Borghini’s Il Riposo (Raffaello Borghini’s The Rest). Toronto: University of Toronto Press.

Ficino, M. (1474). Teologia Platonica, trans. from Latin 1474 edition, annotated and ed. Enrico Vitale Milan: Bompiani, 2011.

Fournié, E., \& Lepape-Berlier, S. (2011). L'Immaculée Conception: une croyance avant d'être un dogme, un enjeu social pour la Chrétienté (The immaculate Conceptions: A belief in front of a dogma, a social issue for Christians). Retrieved from http://acrh.revues.org/4244

Frey, K. (Ed.). (1930). Der literarische Nachlass Giorgio Vasaris (The letters of Giorgio Vasari). (Vols. 1-2). Munich: George Müller.

Geissel, S. (1910). Geschichte der Verehrung Marias im 16. und 17. Jahrhundert. Ein Beitrag zur Religionswissenschaft und Kunstgeschichte (The history of the Virgin Mary in the 16th and 17th centuries. A contribution on the study of religion and art history). Freiburg: Herder Verlag im Breisgau 1910. Retrieved from http://digilander.libero.it/mariaoggi/simbologia.htm\#maria

Härb, F. (2004). Giorgio Vasari entry. In A. Chong (Ed.), Raphael, cellini and a renaissance banker: The patronage of Bindo Altoviti (pp. 406-413). Boston: Isabella Stewart Gardner Museum.

Kallab, W. (1908). Vasari studies. Vienna: W. Grasser and Kiel.

Katzenellenbogen, A. (1959). The sculptural programs of Chartres Cathedral: Christ, Mary, Ecclesia. Baltimore, MD: Johns Hopkins University Press.

Kliemann, J. (1981). Vasari, Pollastra e l’Allegoria della Concezione. In Giorgio Vasari. Principi, letterati e artisti nelle carte di Giorgio Vasari, cat. exp. Arezzo, 1981 (Princes, humanists and artists in the correspondence of Giorgio Vasari, cat. and expo. Arezzo, 1981). Florence: Edam.

Lanzi, L. (1795-96). Storia pittorica della Italia dell'ab (Visual history of Italy), (Vols. 1-2). Venice: Remondini.

Lappoli Pollastra, G. (1505). In laude et gratia della diva et seraphica Catharina da Siena (In Honor and Grace of the Divine and Seraphic Catherine of Siena). Florence.

Male, É. (1913). The gothic image: Religious art in France of the thirteenth century (English trans. of 3rd ed.) London: Collins.

Metford, J. C. J. (1983). Dictionary of Christian Lore and legend. London: Thames and Hudson.

Morello, G., Francia, V., \& Fusco, R. (Eds.). (2005). Una donna vestita di sole. L'Immacolata Concezione nelle opera dei grandi maestri (A woman dressed with the sun. The immaculate conception in the works of the great masters). Rome: Federico Motta.

Night, K. (2012). Dedicated to the immaculate heart of Mary. Retrieved from http://www.newadvent.org/cathen/15464a.htm

Nozedar, A. (2008). Signs and symbols source book. New York: Metro Books.

O’Connor, D. (2000). Giorgio Vasari's allegory of the immaculate conception and its theological tensions. Theological Quarterly, 65, 169-77.

Pilliod, E. (2001). An introduction to Vasari’s story. In Pontormo, Bronzino, and Allori: A genealogy of Florentine Art. New Haven, CT: Yale University Press.

Pisani, R. C. P. (1999). Empoli, il Valdarno inferiore e la Valdelsa fiorentina (Empoli, the lower Valdarno and the Florentine Valdarno). Milan: Mondadori.

Venturi, A. (1901-39). Storia dell'Arte Italiana (History of the Italian Art) (Vols. 1-25). Milan: Ulrico Hoepli.

Rica, G. (1754-62). Notizie istoriche delle chiese fiorentine, divise ne' suoi quartieri (Historical news according to the districts of the Florentine churches) (Vols. 1-4). Florence: P. G. Viviani.

Russell, D. H., \& Barnes, B. (1990). Eva/Ave: Women in the renaissance and baroque prints. Washington, DC: National Gallery of Art.

Temple, J. (2005). Like a fir tree. Retrieved from http://www.livingbiblestudies.org/study/JT9/005.html

The liturgia horarum, common of the blessed Virgin Mary. (R. F. Littledale, Trans.). Retrieved from http://www.preces-latinae.org/-thesaurus/BVM/OGloriosa.html

Tierney, J. C. (Ed.). (2010). The Jesse tree: The fig tree. Retrieved from October 26, 2010, http://campus.udayton.edu/mary/questions/yq/yq70.html

Tronzo, W. (Ed.). (2005). St. Peter's in the Vatican. Cambridge: Cambridge University Press.

Voss, A. (Ed.) (2006). Marsilio Ficino. Berkeley, CA: North Atlantic Books.

Zohary, M. (1982). Plants of the Bible. Cambridge: Cambridge University Press. 